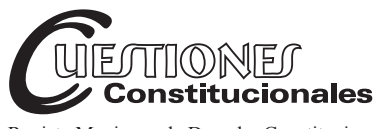

Revista Mexicana de Derecho Constitucional Núm. 42, enero-junio 2020

\title{
The Concept and Instances of General Principles of Administrative Law: Towards a Global Administrative Law*
}

\author{
El concepto y las instancias de los principios generales del derecho \\ administrativo: hacia un derecho administrativo global
}

Arian PETOFT**

\begin{abstract}
RESUMEN: Actualmente, presenciamos el aumento del principio general de los discursos del derecho administrativo en todos los sistemas legales para potenciar los valores de buena administración en los órdenes legales administrativos. En numerosos litigios administrativos, los jueces han invocado algunos casos de principios legales que se imponen al contexto de las acciones del gobierno como criterios modernos y requisitos legales; pero, a pesar del papel normativo determinista del principio general del derecho administrativo, su concepto aún no está definido con precisión. Existen múltiples trabajos meticulosos que identifican el concepto de "principio legal" y sus ejemplos conocidos en los sistemas legales; sin embargo, esencialmente no queda claro si, existencialmente, tenemos principios generales de derecho administrativo en nuestros sistemas legales administrativos. Por lo tanto, este documento se es-
\end{abstract}

ABSTRACT: Nowadays, we are witnessing rise of general principle of administrative law discourses in all legal systems to empower good administration values in administrative legal orders. In numerous administrative litigations, judges have invoked some instances of legal principles which are imposed to the context of government's actions as modern criterions and legal requirements; but, despite of deterministic normative role of general principle of administrative law, its concept is not yet precisely defined. There are multiple meticulous works that identify concept of legal principle and its known examples in legal systems; nevertheless, this essentially remains unclear that if we existentially have general principles of administrative law in our administrative legal systems. Hence, this paper strives to provide a convincible answer to the question by presenting a stringent

* Hereby, i thank my wife, dr. Nahid Rezaei Ali-abad, for all her kind help and guidance. Also, i would like to express my whole gratitude to professor Jan Ziekow who provided insight and expertise that greatly assisted the research; and $i$ am very thankful to all staff of Speyer university for their fruitful supports in the way of writing this paper.

**Assistant Professor of Public Law, Faculty of Law, University of Maragheh, East Azerbaijan, Iran; Gastforscher an der Universität Speyer, Deutschland. E-mail: arian_ petoft@ut.ac.ir; ORCID: https://orcid.org/0000-0001-7491-9632. 
fuerza por proporcionar una respuesta convincente a la pregunta al presentar un discurso estricto sobre la definición del principio general del derecho administrativo y sus posibles instancias en los sistemas legales administrativos, principalmente entre las decisiones de los jueces de la Unión Europea y el Reino Unido - de los cuales representan normas administrativas fundamentales - al descubrir un concepto general preciso de cada uno de ellos en los sistemas legales, se puede hacer un retrato genérico de la cara del derecho administrativo global.

Palabras clave: principio general de derecho administrativo, buena administración, derecho administrativo global, derecho administrativo de la Unión Europea, derecho administrativo del Reino Unido. discourse about definition of general principle of administrative law and its probable instances in administrative legal systems, mostly, among European Union and United Kingdom (UK) judges' decisions; whereof general principles of administrative law represent fundamental administrative norms, by finding out an accurate general concept of each of them in legal systems, a generic portrait of global administrative law face can be drawn.

Keywords: General Principle of Administrative Law, Good Administration, Global Administrative Law, European Union Administrative Law, United Kingdom Administrative Law.

SUMMARY: I. Introduction. II. An effort to enumerate the characteristics: conceptualization and definition. III. Classic principles. IV. Modern principles. V. Conclusion.

\section{INTRODUCTION}

Undoubtedly one of the most important issues of today's public law is general principle of administrative law (GPAL) which its instances have being raised in the context of administrative precedent. There are multiple meticulous works to identify concept of legal principle and its known examples in legal system; however, we might specifically find less considerable works about GPAL. Apart from differences in the definitions are provided by scholars and some contemplative controversial debates in this issue, here clarifying the concept and instances of GPAL is significantly neglected. Most of efforts have presumed a superficial definition and subsequently address the issue by some prevalent instances in administrative precedent. That's while GPALs are increasingly recognized in administrative precedent and effectively play a deterministic normative role in administrative legal order. In numerous cases judges have invoked specific legal principles in administrative litigations to enforce good administration 
values in administrative legal system (ALS) as an efficient way for realization of legality; this leaves a room for counting these principles as GPALs in many legal thoughts. By the way, this essentially remains unclear that if we existentially have GPALs in our ALSs? This main question leads us into a route with several challenging issues about the concept of GPAL, its difference with similar concepts and its probable instances in the context of eminent ALSs; including the question about its precise definition; also, that, are GPALs definitely and absolutely distinguished from similar adjacent legal principles? Is it essentially possible to propose a comprehensive certain list of GPALs? In this regard, this paper strives to provide a convincible answer to the main question, and obviously secondary questions, by presenting a stringent discourse about definition of GPAL and its probable instances in ALSs, mostly, among European Union and United Kingdom (UK) judges' decisions. As a methodological explanation, UK is adopted to investigate its reputational long historical precedent which vocalizes the most momentous ground of UK legal order; besides, EU legal system could present a transnational legal order as the most prosperous cosmopolitan context of legal principles. Whereof GPALs represent fundamental administrative norms, by finding out an accurate general concept of each GPAL in these two legal systems, a generic portrait of global administrative law face can be drawn. Due to augmentation of research's aim to tracing global administrative law, there might be some rooms to slightly interpolate GPALs' instances from other leading legal systems including Germany, the United States and France; there would be no deterministic outline of GPALs, however, because of country's varied legal culture and political compromise during their long history. In order to take steps in the way, first of all the paper endeavors to illustrate the most exact meaning of GPAL by put its characteristics under scrutiny and subsequently, elucidate an approximate general sense of each in the outstanding legal systems to depict a general discourse of new-fashioned global administrative law.

\section{AN EFFORT TO ENUMERATE THE CHARACTERISTICS: CONCEPTUALIZATION AND DEFINITION}

By loaning Aristotle's method, to achieve an appropriate definition of the concept of GPAL, in this section, its characteristics are going to be analyzed. Obviously, GPALs have got all general features of legal principle as well as other sorts. In addition to these, there are some features spe- 
cially belong to GPALs. As a matter of fact, in most of the cases, GPALs generally or specifically are distinguished from similar concepts by these features.

\section{The general features}

Subsequent to Dworkin's core theory of legal principles, ${ }^{1}$ stringent debates, on the concept of these new raised norms in the territory of law, have been raised. In most of the endeavors, we have been witnessing the controversial debates on function and the concept of principles compared with Rules, ${ }^{2}$ however, some fruitful general features could be comprehended. Among the aforesaid specifications by scholars, these features are noteworthy: comprehensiveness, generality, non-positivized, optimization, performance relativity and perpetuity.

\section{A. Comprehensiveness}

By this characteristic, principles can encircle all legal situations and phenomena. Principle has got this property to expand its definition or convey a descriptive proposition to various legal situations. Comprehensiveness gives a trait to encompass diverse commands by which legal vacuum and ambiguity is hermeneutically dispelled. ${ }^{3}$ This feature is realized in the function of principle by optimization exclusivity. For example, to command that "Government's measures should be proportional to existing objective facts"4 in

\footnotetext{
1 See Dworkin, Ronald, Taking Rights Seriously, Harvard, Harvard University Press, 1977.

2 As some significant works, see Alexy, Robert, A Theory of Constitutional Rights, Julian Rivers (trans.), Oxford, Oxford University Press, 2002; Avila, Humberto, Theory of Legal Principles, Netherlands, Springer, 2007; Borowski, Martin, Grundrechte als Prinzipien, 2nd ed., Baden-Baden, Nomos, 2007; Raz, Joseph, "On the Autonomy of Legal Reasoning”, Ratio Juris, vol. 6, No. 1, 1993, p. 1; Hart, H. L. A., "Postscript” in The Concept of Law, Oxford, Clarendon, 1994, p. 238; Shapiro, Scott J., "The Hart-Dworkin Debate: a short Guide for the Perplexed", Michigan Law Public Law and Legal Theory Working Paper Series, No. 77, 2007, p. 1.

3 See Raimo Siltala, A Theory of Precedent: from Analytical Positivism to a Postanalytical Philosophy of Law, Oxford, Hart Publishing, 2000, p. 60.

4 Stone Sweet, Alec and Mathews, Jud, "Proportionality, Judicial Review, and Global Constitutionalism", in Bongiovanni, Giorgio; Sartor, Giovanni and Valentini, Chiara (eds.), Reasonableness and Law, New York, Springer, p. 171.
} 
administrative law or "punishment must be proportionate" in criminal law by principle of proportionality.

\section{B. Generality}

Generality of principle puts miscellaneous instances of related subject matters into the realm of its command. Comprehensiveness gives principle a room to versatility in commands, and generality creates the possibility of diversity in instances inclusion. Essentially, the later feature is a common trait in the nature of legal norms but with a different quality. ${ }^{6}$ Hereto, all principles are general, but some types environ other ones in command. In fact, in comparing two principles, we might find a more general one; that's why GPALs are commonly alluded to depict most foundational administrative law principles ${ }^{7}$ by which multiple principles are derived in the realm of administrative legal order. As an instance, principle of legality comprises principles of statutory interpretation, ultra vires, unauthorized delegation and etcetera.

\section{Non-positivized}

Principle always remains in an abstract sense. In other words, principle would not come off in the contextual configuration of law as rules. Rule may shape the formal structure of principle by an explicit citation, but it doesn't put this underlying assumption forward that the principle was written. Indeed, rule forms the accidental structure of principle; and principle constitutes the essential structure of rule. Somehow, these rules can be considered as definitive written propositions in which substantive interpretive commands of their inherent principles are realized. Principles

5 Duff, Antony and Duff, R. A., Punishment, Communication, and Community, Oxford, Oxford University Press, 2003, p. 132.

6 De Béchillon, M., La Notion de Principe Général en Droit Privé, Paris, U.P. d'AixMarseille, 1998, p. 246.

7 For instance, see Sykes, Edward I.; Lanham, David J. and Tracey, Richard R. S., General Principles of Administrative Law, Butterworths, 1989, p. 10; Peeters, Marjan, "General Principles of Administrative Law and Environmental Principles", in Stroink, F. A. M. (ed.), Judicial Lawmaking and Administrative Law, Oxford, Intersentia, 2005, p. 57. 
are evermore covered by propositions and as a core concept are situated in the content or at the context of rules insofar generally are recognized in a precedent via interpretation. ${ }^{8}$

\section{Optimization}

The inherent structure of a principle contains a discourse in which multifold legal and meta-legal components, containing norms and facts, are implicated. This feature begets any principle adaptability to hierarchical system of legal norms subsumption and also gives rise to rules optimization by substantive interpretation or revision in order to validation. ${ }^{9}$ Accordingly, if a principle's descriptive proposition be found invalid, the principle will be redefined by a new valid one, and this does not collapse its existence. ${ }^{10}$

\section{E. Performance relativity}

Plural normative and factual factors are involved in the inherent discourse of principles causes relatively in their functions. In any case, due to subject matters, principles against each other are placed in an axiological ${ }^{11}$ competition to which, weight evaluation is effectuated; ${ }^{12}$ in which the

8 Claus-Wilhelm, Canaris, Systemdenken und Systembegriff in der Jurisprudenz, Berlin, Duncker \& Humblot, 1983, p. 50.

9 Klement, Jan Henrik, "Common Law Thinking in German Jurisprudence-On Alexy's Principles Theory”, in Klatt, Matthias (ed.), Institutionalized Reason. The Jurisprudence of Robert Alexy, Oxford, Oxford University Press, 2012, p. 173.

10 See Alexy, Robert, "On the Structure of Legal Principles" Ratio Juris, vol. 13, No. 3, 2000, p. 294.

11 About the axiological content of principles, as a distinct characteristic, see Corbí, Marià, Principles of an Epistemology of Values: The permutation of collective cohesion and motivation, London, Springer, 2015, p. 76; Siltala, Raimo, A Theory of Precedent. From Analytical Positivism to a Post-analytical Philosophy of Law, Oxford, Hart Publishing, 2000, p. 58; Dorrien, Gary, Social Ethics in the Making. Interpreting an American Tradition, London, Wiley \& Blackweil, 2009, p. 318.

12 Poscher, Ralf, "The Principles Theory: How Many Theories and What is their Merit?", in Klatt, Matthias (ed.), op. cit., p. 218; Bernal, Carlos, "Legal Argumentation and the Normativity of Legal Norms", in Dahlman, Christian and Feteris, Eveline (eds.) Legal Argumentation Theory. Cross-Disciplinary Perspectives, London, Springer, 2012, p. 103.

Esta obra está bajo una Licencia Creative Commons

Atribución-NoComercial-SinDerivar 4.0 Internacional, IIJ-UNAM. 
principle containing more rational legitimate value and validity, without defeasance, takes priority over the rival one. This hegemony might be reversed in another case. Therefore, as Alexy and Kaufmann have asserted, function of a principle is significantly appertained to coalescent facts and norms in the context of each particular case. ${ }^{13}$

\section{F. Perpetuity}

Since principle has rooted in axiological terms, in the form of an intellectual system, its substance remains consistent and uncontroversial. Principles represent superlative goals of a political-legal system and are not ignorable in the context of norms. They are always engraved in human thought and nature, ${ }^{14}$ whether have got legal reputation and validation by precedent or not. ${ }^{15}$

\section{The special features}

Special features of administrative legal principle are incentive factors by which scholars assign a distinguished group of general principles as GPAL. ${ }^{16}$ This paper stands on this point that administrative legal principle is the same legal principle which is taken by judges in administrative precedent to acquaint it with ALS. Actually, categorizing legal principles into principles of criminal law, ${ }^{17}$ civil law, ${ }^{18}$ administrative law, ${ }^{19}$ constitutional law $^{20}$ and et-

13 Alexy, Robert, "Arthur Kaufmanns Theorie der Rechtsgewinnung”, in Neumann, Ulfrid; Hassemer, Winfried and Schroth, Ulrich (eds.), Verantwortetes Recht: die Rechtsphilosophie Arthur Kaufmannns, Stuttgart, Franz Steiner Verlag, 2005, p. 47.

14 Adams, David M., Philosophical Problems in the Law, 4th ed., California, Thomson and Wadsworth, 2005, p. 53.

15 Wacks, Raymond, Philosophy of Law, Oxford, Oxford University Press, 2006, p. 44.

16 Stroink, F. A. M., Judicial Lawmaking and Administrative Law, Oxford, Intersentia, 2005, p. 57; Cane, Peter, Administrative Law, Oxford, Oxford University Press, 2011, p. 9.

17 Hall, Jerome, General Principles of Criminal Law, New York, Lawbook Exchange, 2010.

18 Reich, Norbert, General Principles of EU Civil Law, London, Intersentia, 2014.

19 Sykes, Edward I., General Principles of Administrative Law, London, Butterworths, 1997.

20 McIntyre Cooley, Thomas, The General Principles of Constitutional Law in the United States of America, New York, BiblioLife, 2016. 
cetera, is only an abstract classification that on the basis of discourse matter and type of precedent is declared. However, principle might be differently recognized in each kind of precedent, its quiddity is the same; it is just described by conceptualized and logically correlated propositions in the context of distinct legal spheres.

In contrast, the dualism ${ }^{21}$ emphasizes on administrative essence of administrative legal principles and the division between general principle of private law and public law. ${ }^{22}$ As it appears in the dualism thought some sort of unshared exclusive principles could be found. Such that some principles are correlative factors between these two spheres of law and also some monopolized ones exist; qua it is depicted as bellow:

\section{FIgURE 1. SCHEMATIC ANALOGICAL SITUATION OF DIFFERENT KINDS OF LEGAL PRINCIPLES IN THE DUALISM THOUGHT}

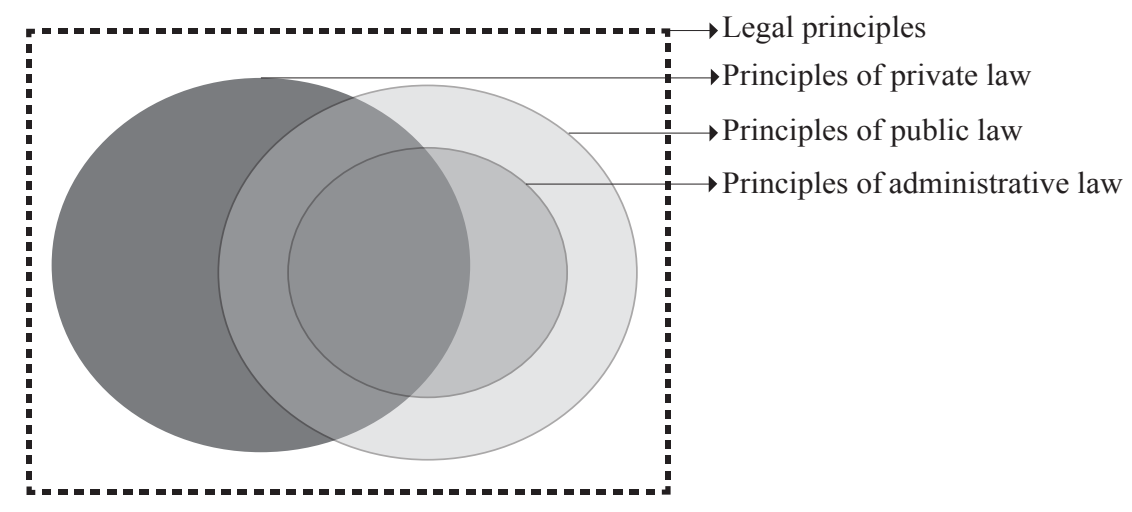

Nevertheless, this idea is going to be faltered by putting optimization and universality substantive features of legal principle into scrutiny. By considering optimization and relativity of principle function, obviously we would find out that it leaves no room to conceive an absolute distinct prin-

21 Barker, Kit and Jensen, Darryn, Private Law. Key Encounters with Public Law, London, Cambridge University Press, 2013, p. 117.

22 Yves, Gaudemet, Droit administratif général: Licence 2e année, les Cours de droit, 1979, Chapitre I et II; Gaston Paul Amédée Jèze, Les principes généraux du droit administratif. Théorie générale des contrats de l'administration. 1934-36, M. Giard, 1936, p. 457; Lebreton, Gilles, Droit administratif general, 4 ed., Paris, dalloz, 2007, p. 53.

Esta obra está bajo una Licencia Creative Commons

Atribución-NoComercial-SinDerivar 4.0 Internacional, IIJ-UNAM. 
ciple. All sorts of principles might be recognized in each one of the realms by judicial proceeding based on some pioneer redefined conceptual propositions or codified rules. Some of these general principles might be simply identified as GPALs in administrative precedent to empower legality and good administration values in ALS; by which administrations' decisions and measures are normalized parallel with legitimate standards and norms; and possible effective administrative remedies are represented.23

Discourses of principles are theoretically and abstractly formed in rulemakers' mind regarding to society's legitimate goals and rationality in the light of the rule of law. Hence, they have a logical and normative correlative links between each other in inherent aspect as well as formal structure which is reflected at the context of propositions; qua principles together have a certain semantic and conceptual order by which coherence and integrity is preserved; to the extent that each principle augments the concept of other ones and fills out their commands in the domain of the rule of law. This might be shown as the figure 2 .

\section{FIGURE 2. A GRAPH DEPICTURE OF LOGICAL AND NORMATIVE CORRELATIVE LINKS (LINES) BETWEEN PRINCIPLES (POINTS) \\ IN THE ABSTRACT STATIC ORDER. THIS REGULAR AND SYSTEMATIC RELATION IS COMPACTED}

IN THE REALM OF THE RULE OF LAW

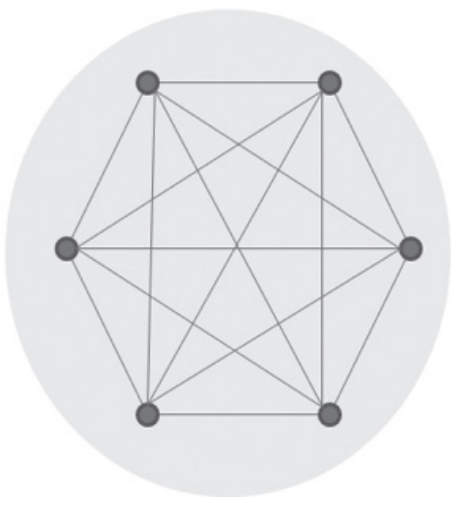

23 Funk, William F.; Shapiro, Sidney A. and Russell, L. Weaver, Administrative Procedure and Practice: Problems and Cases, London, West, 2010; De Leo, John, Administrative Law, Sydney, Cengage Learning, 2008, p. 169. 
As mentioned above, numerous normative and factual components are involved in the inherent discourse of principles that makes it relative in content and be balanced in function. Balancing of principle that sometimes causes normative optimization in legal order, is carried out in the context of any case before a court in which multiple due subject matters take place. In this regard, principle should be conceptualized and relatively redefined due to administrative legal order and matters of any administrative litigation (AL) to be recognized as an administrative legal principle. But it doesn't mean that aforementioned principle would be substantively revolved and from the graph is egressed; as we can clearly observe in the figure 3. As an instance, this kind of adoptability and conceptualization could comprehensibly be apperceived about principles of reasonableness ${ }^{24}$ and legality. ${ }^{25}$

\section{FIGURE 3. A GRAPH DEPICTURE OF THE PARTICIPATION OF PRINCIPLES IN A SPECIFIC AL (DOTTED CIRCLE) AND THEIR ATTENDING BY COMMAND OR REASON}

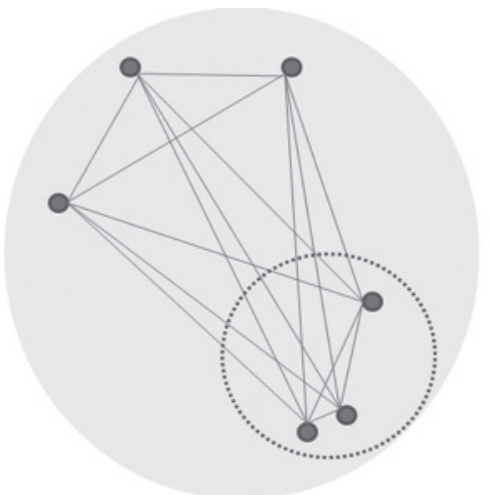

24 Bobeck, Michael, "Reasonableness in Administrative Law: A Comparative Reflection on Functional Equivalence", in Bongiovanni, Giorgio; Sartor, Giovanni and Valentini, Chiara (eds.), op. cit. p.364; Natelson, Robert G., "Reasonableness in Private Law: the Special Case of the Property Owners", Ohio Law Journal, vol. 51, 1990, p. 41; Herring, Jonathan, Criminal Law: Text, Cases, and Materials, Oxford, Oxford University Press, 2014, p. 717.

25 Weeks, Greg, Soft Law and Public Authorities: Remedies and Reform, Oxford, Bloomsbury Publishing, 2016, p. 181; Horrigan, Bryan, Government Law and Policy: Commercial Aspects, Sydney, Federation Press, 1998, p. 319; Freedland, Mark and Auby, Jean-Bernard, The Public Law/Private Law Divide: Une entente assez cordiale?, Oxford, Bloomsbury Publishing, 2006, p.106; Lunney, Mark and Ken Oliphant, Tort Law: Text and Materials, Oxford, Oxford University Press, 2013, p. 493. 
Indeed, each case brings forth own involved components in the realm of principle discourse that affect its command. Therefore, AL attunes principle discourse to administrative legal order while it maintains the graph. So, such a principle would not be substantively altered but has being redefined from case to case. Hence, some sorts which are recognized in administrative precedent might be called administrative legal principles.

Principles, through their deep link discourse with facts and norms, constitute a communication bridge between de facto and de jure spheres; in which, the consequences of discourses in balancing surmount conceptual weakness of law and by creating interventional propositions, gaps are covered. In this way, principles impose their axiological content ${ }^{26}$ and immediate finalistic norms ${ }^{27}$ on the domain of law. Hence the discourse of a specific principle in an ALS is open to other related discourses inspired by other ALSs in order to augment and advance its nature. Hereupon, principles usually are in connection with each other ${ }^{28}$ in the context of a global administrative law in which a nonexclusive group of global GPALs might be conceived. Therefore ALSs are in transition by both internal (national) and external (global) principles' discourses interactions. ${ }^{29}$

Accordingly, these underlying assumptions bring forward two main special features for all administrative legal principles: 1) every administrative legal principle holds forth good administration values in its inherent discourse; 2) they are accredited in administrative precedent as authentic norms in administrative legal order; however, these specifications are accidental and subordinate which are annexed to substantive general features.

26 Bydlinski, Franz, Juristische Methodenlehre und Rechtsbegriff, New York, 2011, p. 289.

27 Sanne, Taekema, The Concept of Ideals in Legal Theory, London, 2003, p. 11.

28 For a dialectical analysis about the role of principles' discourses in a legal order, see Petoft, Arian, "Reviewing the Law of Balancing and Subsumption with the Legal Proposition Factor in the Structure of Principles and Rules", Rechtstheorie, vol. 48, No. 4, 2017, p. 441.

29 Kingsbury, Benedict; Krisch, Nico and Stewart, Richard B., "The Emergence of Global Administrative Law", IILJ Working Paper 2004/1, New York University School of Law, 2004, p. 1; Cassese, Sabino and D'Alterio, Elisa, "Introduction: the development of Global Administrative Law", Research Handbook on Global Administrative Law, 2016, p. 1. 


\section{A. Representative of the good administration values}

In developed ALSs, through reinforcing politics and programs based on good governance and strengthening cornerstones of administrative justice system, striking eagerness are shown to bolster good administration values in administration actions; ${ }^{30}$ in order to constitute a good administration which we might call "Administrative Utopia". Actually, an administrative utopia can be visualized as an administrative system to which effective, efficient, accountable, transparent, responsible, proper, moral, eminent, technical, developed and generally legal performance are described. Nowadays, due to predominant role of judges in legal systems, we are witnessing rise of these values in judicial review in which they've made effective efforts to impose them by imperative valid commands on ALS; in this way, administrative legal principles play a determinative role.

Administrative legal principles by encompassing good administration values in their discourses, command in parallel with them in administrative legal order. This axiological inherent assist administrative legal principle to substantively affecting government actions due to good administration values while procedural legality is maintained. In most of cases, judge tries to validate these axiological norms in administrative legal order by demonstrating their legal reliability based on interpretation inspired by the context or the content of laws. ${ }^{31}$ Among these administrative

30 Meenu, Roy, "Bureaucracy, Development and Good Governance", in Mootheril Raghavan Biju (ed.), Good Governance and Administrative Practices, New Delhi, Mittal Publications, 2007, p. 93; Mashaw, J. L., Bureaucratic Justice: Managing Social Security Disability Claims, London, Yale University Press, 1983, p. 23; Katz, Robert L., Skills of an Effective Administrator, Boston, Harvard Business Review Press, 2008, p. 1; Grimheden, J., "The Right to Good Administration in Multilevel System of the European Union”, in Zhang, Wei; Li, Ruoyu and Yan, Zihan (eds.), Human Rights and Good Governance, Boston, Brill, 2016, p. 109.

31 Judicial rule-making gives rise to several controversial issues about formalism, authority of law, judicial activism and etc. by which this is mainly questioned that to what extent judicial reasoning, interpretation and rule-making could be authoritative. To read some noteworthy works about judicial activism, see La Torre, Massimo, "Between Nightmare and Noble Dream: Judicial Activism and Legal Theory", in Pereira Coutinho, Luís; La Torre, Massimo and Smith, Steven D. (eds.), Judicial Activism. An Interdisciplinary Approach to the American and European Experiences, London, Springer, 2015, p. 3; D'Amato, Anthony, "Judicial Legislation", Northwestern University School of Law Scholarly Commons: Faculty Working Papers, 2010, p. 1; Magrish, James L., "Judicial Legislation, by Fred V. Cahill”, Indiana Law Journal, vol. 28, No. 2, 1953, p. 282; 
legal principles, GPALs are the most general norms in ALS which in turn are representative of the most legitimate fundamental good administration values. Hereby, some GPALs mostly emphasize on traditional values in legality of ALS and some others in a modern sense mainly corroborate the substantive aspect of good administration. However, the earlier ones are reconciled with modern requirements, but as a matter of legally antecedent objectivity might be categorized into "Classic Principles"; and the latter ones could be remarked as "Modern Principles". Good administration values in the discourse of classic principles uphold primary obligations that should be considered in all government actions; these norms are almost stood in legal tradition by which formalism and procedural aspect of the rule of law as well as equity and fundamental rights are strongly preserved. Beside them, modern principles embrace some novel good administration values which are recently brought in ALS that, for the most part, emphatically strengthen substantive rule of law.

Kmiec, Keenan D. "The Origin and Current Meanings of Judicial Activism”, California Law Review, vol. 92, No. 5, 2004, p. 1441; Cross, Frank B. and Lindquist, Stefanie A., "The Scientific Study of Judicial Activism", University of Minnesota Law Review, vol. 91, No. 6, 2007, p. 1752; Moses, Margaret L., "Beyond Judicial Activism: When the Supreme Court is nNo Longer a court", Journal of Constitutional Law, vol. 14, No. 1, 2011, p. 161. To Read some works about authority of law, see Raz, Joseph, "Legal Reasons, Sources and Gaps," The Authority of Law: Essays on Law and Morality, Oxford, Clarendon Press, 2009, p. 53; Raz, Joseph, "Authority, Law and Morality", Ethics in the Public Domain, Oxford, Clarendon Press, 1994, p. 194; Raz, Joseph, The Concept of a Legal System, 2nd ed., Oxford, Clarendon Press, 1980, p. 211; Kramer, Matthew H., In Defense of Legal Positivism: Law without Trimmings, Oxford, Oxford University Press, 2003, p. 78; Borowski, Martin, “The Structure of Formal Principles-Robert Alexy's Law of Combination”, On the Nature of Legal Principles, Nomos, Stuttgart, 2010, p. 26. Also, as some prominent works on formalism and judicial interpretation, see Sieckmann, JanReinard, Regelmodelle und Prinzipienmodelle des Rechtssystems, Baden-Baden, Nomos, 2009, p. 162; Sieckmann, Jan-Reinard, "Probleme der Prinzipientheorie der Grundrechte", in Clérico, Laura and Sieckmann, Jan-Reinard (eds.), Grundrechte, Prinzipien und Argumentation, Baden-Baden, Nomos, 2009, p. 39; Enderlein, Wolfgang, Abwagung In Recht Und Moral, Munich, Alber, 1992, p. 338; Kaufmann, Marcel, "Politische Gestaltungsfreiheit als Rechtsprinzip", Staatswissenschaften und Staatspraxis, vol. 8, 1997 , p. 161; Alexy, Robert, "Verfassungsrecht und einfaches Recht", Veröffentlichungen der Vereinigung der Deutschen Staatsrechtslehrer, vol. 61, 2001, p. 7; Raabe, Marias, "Grundrechtsschutz und Gesetzgeberischer Einschätzungsspielraum: Ein Kon- struktionsvorschlag", in Grabenwarter, Christoph et al (eds.), Allgemeinheit der Grundrechte und Vielfalt der Gesellschaft, Stuttgart, Kohlhammer, 1994, p. 83; Raabe, Marias, Grundrechte und Erkenntnis: Der Einschätzungsspielraum des Gesetzgebers, Baden-Baden, Nomos, 1998, p. 207. 


\section{B. Recognition in administrative precedent}

As mentioned, administrative legal principles are recognized by judges in administrative precedent. Maxims, postulates and some other kinds of similar concepts, so long as principles are not legitimately identified in administrative precedent, wouldn't be treated as administrative legal principles; this is certainly because of preservation of authoritative characteristic of law and importing valid norms in administrative legal order. Administrative precedent in a civil law system is individually referred to administrative court proceeding ${ }^{32}$ whereas it is a technically court proceeding related to cases require administrative litigations by nature in a common law system. In either case, respective precedent intelligibly clarifies the most known and prevalent GPALs.

\section{Providing a definition}

Consequently, these aforesaid features shed light on the way to definition of GPALs. Hereby, we might eventually define them as "of the most general, comprehensive, non-positivized and perpetual legal norms which are legitimately recognized in administrative precedent by judges and relatively function in parallel with good administration values in ALS in order to optimize administrative legal order or realize the rule of law in government actions." GPALs can be categorized into classic principles and modern ones regarding to antecedent objectivity in the realm of ALS. Their inherent discourses are flexible in conceptualization but strongly remain in logical and normative correlative links in such a way that their integrity is always retained. Hereupon, a universal analogical discourse, by bringing GPALs in the context of legal systems together, could be obtainable. However, every one of GPALs invites us to a comprehensive broad investigation, but in this research, generic sense of them is thought-out.

\section{CLASSIC PRINCIPLES}

Above-mentioned classic GPALs are some principles rooted in tradition of law and have got long background in precedents; however, due to

\footnotetext{
32 Such as Conseil d'État in France and Bundesverwaltungsgericht in Germany that are at the head of their administrative courts.
} 
modernization, they have being conceptualized during the time. ${ }^{33}$ Among them, principle of the rule of law is the most general one which encompass all other principles. In UK legal tradition, general principle of equity, and in EU, USA, France and German law, constitutional rights principles are of the most highlighted GPALs which can be abstractly situated at the top of hierarchical system of legal norms in the light of the rule of law. ${ }^{34}$ However, these super-principles are robustly applied in most of ALSs by principle of legality in a general sense in order to protect fundamental rights, which are reflected in Constitution, adherence to law and vindication of justice as a genuine goal of it. As a matter of fact, by pondering on precedents, we might probably acknowledge these principles of the most known GPALs in ALSs: the rule of law, legality, ultra vires, error, unauthorized delegation, equality, harm, remedy, equity and constitutional rights principles. These principles are inextricably twisted in concept by their discourses; howbeit, they are separately recognized and can be independently defined as an autonomous norm in administrative precedent in which judges invoke them on numerous occasions.

\section{The rule of law}

It is simply could be said that the rule of law determines boundary dissociation between the realm of law and meta-legal domains. The principle, through law authority maintenance, establishes a legal order in which law governs instead of pure power. ${ }^{35}$ Hence, it keeps government under legally normative control by which any arbitrariness is rebuffed. This takes steps in the way of validity preservation of any behavior and norm in the sovereign territory. To the extent that, each one of phenom-

33 Petoft, Arian and Markaz-malmiri, Ahmeh, Concept and Scope of the General Principles of Administrative Law and Referring Possibility in the Judicial Procedure, Teheran, Iranian Judiciary Research Institute, 2016, p. 91.

34 The most known modern GPAL in EU legal system are the affiliated principles of right to good administration including non-discrimination, legal certainty, fairness, objectivity and impartiality, participation, proportionality, protection of legitimate expectations, transparency, and due access to effective remedies, efficiency, effectiveness and etc., see Hofmann, Herwig C. H.; Schneider, Jens-Peter and Ziller, Jacques (eds.), Model Rules on EU Administrative Procedure, ReNEUAL, 2014, p. 45.

35 Rose, J., "The Rule of Law in the Western World: An Overview", Journal of Social Philosophy, vol. 35, No. 4, 2004, p. 457. 
ena should be realized in accordance with law. Therefore, the rule of law is the most general principle which eclipses other ones in its imperative sphere. ${ }^{36}$

Whereof by establishment of government, freedoms are restricted and coercive power is imposed, then to exclude any kind of tyranny or authoritarianism, protection of the rule of law is indispensable and crucial. To be under the rule of law means legitimately governing by certain legal rules which John Locke has defined as neutral constant-based rules that are equitable to all. ${ }^{37}$ Currently, one of the most substantial means of the rule of law preservation is judicial control over government actions ${ }^{38}$ by which citizens' rights are protected ${ }^{39}$ and various binding GPALs are technically provided; as much as even there is a theory of "judicial democracy" amongst doctrines. ${ }^{40}$ Protection of substantive sense of the rule of law crucially depends on effective judicial review of authorities' decisions and measures by proper standards derived from accredited GPALs. Indeed, substantive aspect of the rule of law enables axiological norms to present and role-play in the domain of law as a gateway; here is the main area of dialectic debate between naturalists and positivists regarding to conceptual scope of the substantive sense in connection with the procedural one which fortifies legal formalism. ${ }^{41}$ This is why we might apprehend moraloriented and fair norms and themes in the spirit of laws.

Both dimensions of the rule of law are plainly reflected in USA precedent. ${ }^{42}$ In this regard, substantive conditions alongside procedural ones

36 Dicey, A. V., Introduction to the Study of the Law of the Constitution, Oxford, Lightning Source, 2009, p. 183.

37 Locke, John, Two Treaties of Government, London, Cambridge University Press, 1988 , p. 324.

38 Beckett, Julia, Public Management and the Rule of Law, London, M. E. Sharpe, 2010, p. 6.

39 Petoft, Arian and Jamshidi, Alireza, "Citizens' Rights in the Light of Modern Administrative Procedures”, Bioethics Journal Quarterly, vol. 6, No. 21, p. 23.

40 See Manfredi, Christopher and Rush, Mark, Judging Democracy, Toronto, University of Toronto Press, 2013.

41 Kramer, Matthew H., "On the Moral Status of the Rule of Law", Cambridge Law Journal, vol. 63, No. 1, 2004, p. 65.

42 Hall, James Parker, Constitutional Law, Charleston, BiblioBazaar, 2009, p. 1; Edward, W., The Constitution and the New Deal, Harvard University Press, 2000, p. 25; Bickel, A., The Least Dangerous Branch: the Supreme Court at the Bar of Politics, Yale University Press, 2011, chapter I; Petoft, Arian and Vijeh, Mohammadreza, "Due Process 
oblige government to observe in any sort of action; as it is beheld in UK. As a matter of fact, assigned discretionary power (DP) to authorities doesn't mean that they have absolute discretion in fulfillment the legal duties by their wisdom; rather they should put rational considerations in observation. ${ }^{43}$ Furthermore, they should observe proportionality implications while merit of their decisions is notably evident. ${ }^{44}$ This can illustrate the reason that French legal system tremendously applies substantive GPALs in numerous contexts of cases by administrative precedent ${ }^{45}$ In comparison, the rule of $\mathrm{law}^{46}$ similarly plays a momentous role in german law, however, mainly stresses on the principle of "democracy" and "constitutional rights" ${ }^{\prime 7}$ as the most revolutionary intellectual commitments which are twentieth century thought relics. ${ }^{48}$ Thus, constant judicial control over government based on the rule of law is a pretext to protect citizens' rights and democracy; in essence, existence of constitutional litigation ${ }^{49}$ before the "Federal Constitutional Court" ${ }^{50}$ - that makes german law unique and unparalleled - is an unequivocal testifier of that. In the context of german law, principle of the rule of law analogically is a normative way to the justice; hence, realization of the rule of law is potentially appertained to be under the behests of the way ${ }^{51}$ as if by legality. ${ }^{52}$

The rule of law contains a broad sense in which legality, proportionality, reasonableness, respecting to rights and other principles are included

of Law in the United States Judicial Review”, Shiraz University Journal of Legal Studies, vol. 8, No. 4, 2017, p. 1.

43 Associated Provincial Picture Houses Ltd. v. Wednesbury Corporation, 1948, 1 KB 223, available at: https://lawcasesummaries.com/knowledge-base/associated-provincialpicture-houses-ltd-v-wednesbury-corporation-1948-1-kb-223.

44 Brind and others v. Secretary of State for the Home Department, 199,1 1 A.C. 696, available at: https://www.lawteacher.net/cases/r-v-brind-1991.php.

45 See Brown, L. N., French Administrative Law, Oxford, Clarendon, 1998, p. 2.

46 It is known as Rechtsstaatlichkeit in GL.

47 Stolleis, M., Geschichte des öffentlichen Rechts, Zweiter Band, Staatsrechtslehre und Verwaltungswissenschaft 1800-1914, Munchen, V. W. de Gruyter, 1992, p. 241.

48 Künnecke, Marina, Tradition and Change in Administrative Law: An Anglo-German Comparison, Berlin, Springer, 2007, p. 21.

49 Schwarze, J., Das Verwaltungsrecht unter europäischem Einfluß, Baden-Baden, Nomos, 1999, p.197.

50 Bundesverfassungsgericht (BVerfG)

51 Bockenforde, E. W., State, Society and Liberty, Berlin, Berg, 1991, p. 47.

52 BVerfGE49, 89, 126, available at: http://www.servat.unibe.ch/dfr/bv049089.html. 
and even supranational norms are guaranteed. The latter is stringently protected by the principle of "legal certainty" in EU law; according to which any obligation by laws or other kind of binding means, that is compulsorily dominated to european citizens, should has minimum legitimate quality and form while the primary requirements of justice and fairness are precisely observed. ${ }^{53}$ As a consequence, legal certainty required that in exercising any kind of DPs, authority cannot violate general conditions of freedoms which are guaranteed by EU law. ${ }^{54}$ It protects all GPALs of EU law, ${ }^{55}$ which are essentially lain in broad sense of the rule of law, in the sovereign territory of EU member states by empowering the principle of "supremacy" (supremacy of EU law over national law) to establish a global government (globalization) ${ }^{56}$ with two-level implication of the rule of law (national and international law). ${ }^{57}$ This might be assumed as a cosmopolitan law which is a direct result of EU's the rule of law; it is such an alternative to traditional thought of international law.

\section{Legality}

In all legal systems, principle of legality is audibly identified with a clear sound of compliance with law which drafts this assumption that anyone should act by the way that is prescribed by law..$^{58}$ Influenced by liberalism

53 Raitio, Juha, "The Principle of Legal Certainty as a General Principle of EU Law", in Bernitz, Ulf et al (eds.), General Principles of EC Law in a Process of Development, New York, Kluwer Law International, 2008, p. 47.

54 Hashman and Harrup v. United Kingdom, 2000, 30 EHRR 241, available at: http:// opil.ouplaw.com/view/10.1093/law:ihrl/2821echr99.case.1/law-ihrl-2821echr99.

55 Ratio, Juha, The Principle of Legal Certainty in EC Law, London, Springer, 2014, p. 95.

56 Glanville, L., "The Antecedents of Sovereignty as Responsibility", European Journal of International Relations, vol. 17, No. 2, 2011, p. 233; Scholte, J. A., Globalization: A Critical Introduction, New York, Palgrave Macmillan, 2000, p. 15; Lederer, M., Criticizing Global Governance, New York, Palgrave Macmillan, 2005, p. 26; Ku, J., and Yoo, John, "Globalization and Sovereignty", Berkeley Journal of International Law, vol. 31, No. 1, 2013, p. 210.

57 148/78 Ratti [1979] ECR 1629, available at: https://eur-lex.europa.eu/legal-content/EN/ TXT/? uri=CELEX\%3A61978CJ0148; 152/84 Marshall [1986] ECR 723. https://webstroke. co.uk/law/cases/case-15284-marshall-v-southampton-health-authority-marshall-i-1986.

58 Fox-Decent, Evan, "Unseating Unilateralism”, in Austin, Lisa M. and Klimchuk, Dennis (eds.), Private Law and the Rule of Law, Oxford, Oxford University Press, 2015, p. 116.

Esta obra está bajo una Licencia Creative Commons

Atribución-NoComercial-SinDerivar 4.0 Internacional, IIJ-UNAM. 
thoughts, citizens are free to decide and act except where laws forbid; accordingly this is a principle that all actions in private sphere are legal unless contrary is proved. ${ }^{59}$ In contrast, in public sphere due to legitimate governance committals, the principle is that authorities could not act apart from in cases where a law assigned. ${ }^{60}$ So in private relationships the positive sense of legality and in public ones, the negative sense of it is proposed. The earlier may be called as principle of "capacity" and the latter can be singled out as principle of "incompetency". The latter is the same principle in light of L'Etat du Droit in French legal system by which government should do only what is determined by law. In fact, it can be an outcome of mistrust of government and its authorities to keep their actions within the framework of democratic legal norms to make them licit as a normative lawful power. ${ }^{61}$

Therefore, principle of legality protects obligation and enforcement of law; somehow the hierarchical system of norms as well as legitimacy of behaviors is preserved. This calls up manifold sub-principles such as "Nulla Poena Sine Lege" (no punishment without law) in $\mathrm{UK}^{62}{ }^{62} \mathrm{E}^{63}$ and so on which holds legality of punishments or "non-retroactive" rule of previous law on the former situations (legality in the past); also the second one pinpoints prohibition of extending effects and consequences of authority's decisions to the past. ${ }^{65}$ In addition, legality implies princi-

59 See Connolly, Niamh "We'll Meet Again: Convergence in the Private Law Treatment of Public Bodies", in Robertson, Andrew and Tilbury, Michael (eds.), The Common Law of Obligations: Divergence and Unity, Oxford, Hart Publishing, 2016, p. 175.

60 See Seerden, René and Stroink, F. A. M., Administrative Law of the European Union, Its Member States and the United States. A Comparative Analysis, New York, Intersentia, 2002, p. 12.

61 Kriegel, Barret, "État de droit", in Dictionnaire constitutionnel, Paris, Puf, 1992, p. 415; Loschak, D., Le principe de légalité. Mythe et mystification, Actualité juridique, Droit administratif, 1981, p. 387; Leisner Walter, L'Etat de droit, une contradiction, Melanges Eisenmann, Paris, Cujas, 1975, p. 65.

${ }^{62} R$ v. Mistra and Srivastava, 2004, EWCA Crim 2375, available at: https://www. lawteacher.net/cases/r-v-misra-srivastava.php; $R$ v. Rimmington, 2005, UKHL 63, available at: https://uk.practicallaw.thomsonreuters.com/D-000-0514.

63 Jorgic v. Germany, 2007, ECHR 583, available at: https://hudoc.echr. coe.int/app/conversion/pdf/? library $=$ ECHR\&id $=003-2055877-2175646 \&$ filena $m e=003-2055877-2175646 . p d f \& T I D=$ thkbhnilzk.

64 Brown, Lionel Neville, op. cit., p. 236.

65 As it is clear in EU precedent: Case 63/83 Kirk,1984 ECR 2689, available at: https://webstroke.co.uk/law/cases/case-6383-r-v-kirk-1984; Case 80/86 Officer van Justitie v. Kolpinghuis Nijmegen BV, 1987, ECR 3969, available at: http://eur-lex.eu- 
ple of "compliance" that almost famed by beachtung in german law; 66 according to which, authorities should conform to legal rules ${ }^{67}$ and this at a later date entails accountability and reasonableness (providing rational reasons to justify action undertaken) as modern principles in ALSs. ${ }^{68}$ Besides, principle of "statutory interpretation" is one of incontrovertible normative sequences of legality that holds any interpretation of legal provisions, which is suggested by public officials or judges, into the framework of law's prescribed commands to prevent a probable diversion of context of law. ${ }^{69}$

Further, principle of legality chiefly evokes principles of "excess of discretion", "exercise discretion" and "abuse of discretion" in german law; $;^{70}$ the first two principles mainly emphasize on procedural legality whiles the latter remarks substantive one which is placed among the modern principles by and large. The excess principle gives the meaning of incompetency: where it is not permissible by law, there is no discretion; this unambiguously holds forth "ultra vires" principle in UK which is in proximity of "error" principle that collectively reinforces legality. ${ }^{71}$ The exercise principle compels competent authorities to fulfill their legal duties ${ }^{72}$ and this is not about breaching competency boundary. In abuse of power, discretion is exercised and also

ropa.eu/resource.html? uri =cellar:09d07fa8-c68a-4212-9930-92b97193c86a.0002.06/ DOC_2\&format $=P D F$; Dansk Rorindustri and Others v. Commission, 2005, available at: http://curia.europa.eu/juris/liste.jsf?num $=C-189 / 02$ \&language $=$ en; Archer Daniels Midland Ingredients Ltd v. Commission, 2006, available at: http://curia.europa.eu/juris/ liste.jsf? language $=$ en\&num $=C-397 / 03 ; B A S F$ and $U C B$ v. Commission, 2007, available at: http://europa.eu/rapid/press-release_CJE-07-90_en.htm.

66 Schwarze, Jürgen, "European Administrative Law", The European Communities Publications, 2006, p. 887.

67 Harlow, Carol and Richard Rawlings, Law and Administration, London, Cambridge University Press, 1997. p. 37.

68 Endicott, Timothy, Administrative Law, Oxford, Oxford University Press, 2015, p.15; Elliott, Mark and Varuhas, Jason, Administrative Law. Text and Materials, Oxford, Oxford University Press, 2017, p.594; Thompson, Brian and Michael Gordon, Cases and Materials on Constitutional and Administrative Law, Oxford, Oxford University Press, 2014, p.228.

69 Funk, William F. and Seamon, Richard H., Administrative Law: Examples and Explanations, New York, Aspen Publishers, 2008, p. 281.

70 Künnecke, Marina, op. cit. p. 37.

71 Carroll, Alex, Constitutional and Administrative Law, 5th ed., Munich, Longman, 2009, p. 317.

72 BverwGE92, pp. 153 and 154.

Esta obra está bajo una Licencia Creative Commons

Atribución-NoComercial-SinDerivar 4.0 Internacional, IIJ-UNAM. 
no exceedance has taken place; but an authority applied her/his power in a misuse way while principle of error interdicts her/him of any unintentionally error of law or jurisdictional fact.

In the context of EU law, legality implies a two-level object which envelop national and international mandate of its substandard normative command. This unequivocally puts forward some pertinent sub-principles by which the member states are obliged to observe in the both levels along with legality observation in the Union bodies themselves. These sub-principles, by their most significant instances, can be enumerated as principles of "loyalty", "efficiency", "assimilation", "solidarity", "direct effects", "indirect effects" and "direct applicability". Loyalty ${ }^{73}$ and efficiency principles, through mutual co-operation, leads states' policies and measures to the way in which integrity of EU and its legal order are effectively exerted and maintained. ${ }^{74}$ Assimilation $^{75}$ and solidarity ${ }^{76}$ principles robustly fortify EU law coherence and correlation between international legal order with national one; in this regard, the member states are committed to legislate and implement in compliant and consistent with the EC treaty's conditions. ${ }^{77}$ Direct effects principle creates a possibility for lawsuit before a national court by EU law particularly about guaranteed european citizens' fundamental rights ${ }^{78}$ and principle of indirect effect necessitate national laws interpretation congruent and compatible with EU law especially in the context of judicial explanation of rules. ${ }^{79}$ Finally, all member states should directly

\section{Article 10 EC Treaty}

74 See Gormley, Laurence W., "General Principles of Law whithin Article 10 EC", in Bernitz, Ulf et al (eds.), General Principles of EC Law in a Process of Development, New York, Kluwer Law International, 2008, p. 307; also to read some instance of related cases, see 106/77 Simmenthal, 1978, ECR 629; 222/86 Unectef v. Heylens, 1987, ECR 4097.

75 Article 280 EC Treaty.

76 Article 158 EC Treaty.

77119 \& 126/79 Lippische Hauptgenossenschaft, 1980, ECR 1863, available at: http://curia.europa.eu/juris/showPdf.jsf?text $=\&$ docid $=90826 \&$ doclang $=E N$.

78 C-149/96 Portugal v. Council, 1999, ECR 1-8395, available at: http://cjel.law. columbia.edu/print/2001/case-law-case-c-14996-portuguese-republic-v-council-of-theeuropean-union-eur-ct-j-november-23-1999-1999-e-c-r-1-8395; C-431/93 van Schijndel, 1995, ECR 1-4705, available at: https://eur-lex.europa.eu/legal-content/EN/TXT/ PDF/? uri=CELEX:61993CJ0430_SUM\&from=EN. C-91/92 Faccini Dori [1994] ECR 1-3325, available at: http://curia.europa.eu/juris/showPdf.jsf?text $=\&$ docid $=99835 \&$ doc lang $=E N$.

79 80/86 Kolpinghuis, 1987, ECR 3969, available at: https://swarb.co.uk/criminal-proceedings-against-kolpinghuis-nijmegen-bv-ecj-8-oct-1987; C-I06/89 Marleas- 
apply EU law conditions and norms into their legal system based on principle of direct applicability primary command. ${ }^{80}$

\section{A. Ultra vires}

Ultra vires is a well-known concept in UK. Due to that, any excess of discretion is considered as a violation of legality. ${ }^{81}$ Principally, there would be no discretion in public sphere unless such a competency is ordained by law. Hence, authority should act into competency boundary which conferred upon by law; this phrase affirms non-arbitrariness principle in a narrow sense. ${ }^{82}$ Likewise, EU law applies the principle to harness the power in the deterministic legal framework. ${ }^{83}$ It should be noted that the principle does not downright refer to executive power; either it covers all sort of legal powers. For instance, jurisdiction of courts; or particularly "non-justiciability" principle in USA ${ }^{84}$ that is appropriated for inhibition of hearing to cases containing political and security challenging issues in

ing, 1990, ECR 1-4135, available at: https://eur-lex.europa.eu/legal-content/EN/TXT/ PDF/? uri=CELEX:61989CJ0106_SUM\&from=IT;C-334/92 WagnerMiret, 1993ECR1-6911, available at: https://eur-lex.europa.eu/legal-content/HR/TXT/?uri=CELEX:61992CJ0334.

80 111/75 Mazzalai, 1976, ECR 657, available at: http://curia.europa.eu/juris/liste. jsf?language $=$ en\&num $=C-111 / 75.43 / 75$; Defrenne v. Sabena, 1976, ECR 455, available at: https://eur-lex.europa.eu/legal-content/EN/TXT/? uri=CELEX\%3A61975CJ0043.

$81 R$ v. Richmond upon Thames Council, ex p McCarthy and Stone Ltd, 1992, 2 AC 48, available at: https://mdx.rl.talis.com/items/F3E4C6DE-A113-2B8B-161CA026CA894D23.html; Hazell v. Hammersmith and Fulham Council, 1992, 2 AC 1. Available at: https://www.braintree.gov.uk/download/downloads/id/7648/exd021c_hazell_v_ hammersmith_fulham_lbc_1992_2_ac_1.pdf.

82 Willcox Seidman, Ann; Seidman, Robert B. and Abeyesekere, Nalin, Legislative Drafting for Democratic Social Change: A Manual for Drafters, New York, Kluwer Law International, 2001, p. 151. As some instances of cases about non-arbitrariness in UK precedent: Entick v. Carrington, 1765, EWHC KB J98, available at: https://www.lawteacher.net/cases/entick-v-carrington-1765.php; $R$ v. Secretary of State for Social Services, ex parte Stitt, 1990, available at: https://swarb.co.uk/regina-v-secretary-of-state-forsocial-services-ex-parte-child-poverty-action-group-ca-1989; Malone v. Metropolitan Police Commissioner, 1979, available at: https://www.lawteacher.net/cases/malone-vmetropolitan-police-commissioner.php.

83 Hofmann, Herwig C. H.; Rowe, Gerard C. and Türk, Alexander H., Administrative Law and Policy of the European Union, Oxford, Oxford University Press, 2011, p. 173.

84 Rose-Ackerman, Susan and Lindseth, Peter L., Comparative Administrative Law, London, Edward Elgar Publishing, 2010, p.148.

Esta obra está bajo una Licencia Creative Commons

Atribución-NoComercial-SinDerivar 4.0 Internacional, IIJ-UNAM. 
which, because of presumably disruption of "check and balance", ${ }^{85}$ there is no jurisdiction to judicial review. ${ }^{86}$

\section{B. Exercise discretion}

Also, by an alternative exposition of ultra vires principle, might be said that any compulsory or discretionary power is a legal duty should be performed by competent authority and abstain of this task, in turn, is an action that is not permitted by law; it accounts principle of exercise discretion in german law and mainly consider as illegality of action in ALSs.

\section{Error}

Error of law and error of facts are two common principles particularly in UK precedent and in most of cases are conceptualized under the extensive concept of legality in ALSs ${ }^{87}$ In error of law, an authority makes a mistake by misunderstanding of law specifically about her/his discretion ${ }^{88}$ whereas error of fact is arisen in cases in which she/he errs in compliance objective

85 Endicott, Timothy, op. cit., p. 250; Tushnet, Mark; Fleiner, Thomas and Saunders, Cheryl, Routledge Handbook of Constitutional Law, USA, Routledge, 2013, p. 382.

86 Railroad Comm'n of Texas v. Pullman Co.-312 U.S. 496, 1941, available at: https:// supreme.justia.com/cases/federal/us/312/496; Baker v. Carr, 369 U.S. 186, 1962, available at: https://supreme.justia.com/cases/federal/us/369/186; Luther v. Borden, 48 U.S. 1, 1849, available at: https://supreme.justia.com/cases/federal/us/48/1; Holtzman v. Schlesinger-414 US 1316, 1973, available at: https://supreme.justia.com/cases/federal/ us/414/1316.

87 Mason, Sir Anthony and Lindell, Geoffrey, The Mason Papers. Selected Articles and Speeches, Federation Press, 2007, p. 183; Wolf, Susan and Stanley, Neil, Wolf and Stanley on Environmental Law, London, Routledge, 2013, p. 569; Cane, Peter, Controlling Administrative Power. An Historical Comparison, Cambridge, Cambridge University Press, 2016, p. 209.

88 v. Northumberland Compensation Appeal Tribunal, ex parte Shaw, 1952, 1 KB 338, available at: https://swarb.co.uk/regina-v-northumberland-compensation-appealtribunal-ex-parte-shaw-ca-19-dec-1951; Anisminic v. Foreign Compensation Commission, 1969, 2 AC 47, available at: https://swarb.co.uk/anisminic-ltd-v-foreign-compensation-commission-hl-17-dec-1968; $R$ v. Somerset CC, ex p Fewings, 1995, 3 All ER 20, available at: https://swarb.co.uk/regina-v-somerset-county-council-ex-parte-fewingsand-others-ca-22-mar-1995. 
instances with respective legal commands. ${ }^{89}$ In a sense, it can be understood as a kind of excess of discretion from this perspective that authority has acted out of her/his competency boundary and not in conformity with the law.

\section{Unauthorized delegation}

Discretions which are allocated by laws to public officials should be exercised personally by respective competent authority. Principally, authorities cannot fulfill tasks on behalf; therefore, they are not allowed to delegate unless such a delegation is guaranteed by law or are implicitly supposed in its rules; $;^{90}$ ergo, as it is explicit in $\mathrm{UK}^{91}$ and German ${ }^{92}$ precedents, delegation is an exception that necessitates a legal allowance. Whereof any delegation should be authorized by law, then we might embody its command as a principle of competency; which means that delegation itself is an extra-discretion that should be prescribed by law. Even in cases of legal authorization, three kinds of delegation are not allowed unless by an exceptional permission of law: transverse delegation in which power is dedicated to an authority by another one in the same level of administrative hierarchy; ${ }^{93}$ longitudinal delegation by a lower grade authority to an upper one in administrative hierarchy; however, there are some exceptions to longitudinal delegation that the most considerable could be principle of "subsidiarity" in EU law by which the Union in some exceptional circumstances shall act instead of the member states if and insofar as the objectives of the proposed action cannot be sufficiently achieved by

89 White and Collins v. Minister of Health, 1939, 2 KB 838, available at: https://www. academia.edu/35327325/ADMINISTRATIVE_LAW.

90 Webley, Lisa and Samuels, Harriet, Complete Public Law, Oxford, Oxford University Press, 2012, p. 490.

91 Barnard v. National Dock Labour Board, 1953, available at: https://webstroke. co.uk/law/cases/barnard-v-national-dock-labour-board-1953; $R \quad v$. Race Relations Board, 1975, available at: https://webstroke.co.uk/law/cases/r-v-race-relations-boardex-p-selvarajan-1975.

92 Maurer, Hartmut, Allgemeines Verwaltungsrecht, 19th ed., Berlin, V. W. de Gruyter, 2017, p. 505.

93 See Lavender \& Son Ltd v. Minister of Housing, 1970, 3 All ER 871, available at: https://swarb.co.uk/lavender-v-minister-of-housing-and-local-government-1970; Audit Commission v. Ealing Council, 2005, EWCA Civ 556, available at: https://www.cascaidr. org.uk/2017/03/23/the-audit-commission-for-england-and-wales-v-ealing-boroughcouncil-2005-ewca-civ-556.

Esta obra está bajo una Licencia Creative Commons

Atribución-NoComercial-SinDerivar 4.0 Internacional, IIJ-UNAM. 
them; ${ }^{94}$ and finally, consecutive delegation that means subsequent delegation by delegated authority to another one. ${ }^{95}$

\section{E. Equality}

One of the most fundamental principles in all ALSs is principle of equality. Article 2 of the Declaration of Human Rights and article 26 of the International Covenant on Civil and Political Rights significantly guarantee right to equality. Equality principle protects citizens by law and under the law equally. Government should provide justly law in which citizens are equal by the provisions in rights and privileges and also are equally protected under its enforcement. In addition, government action should be impartial qua all citizens could be able to effectually make a profit of that without any illegal discriminatory concession. Hence, this principle in a negative sense is called "non-discrimination"; 96 for example prohibition of discrimination by $\operatorname{sex}^{97}$ or workers' wage ${ }^{98}$ in EU case law.

\section{F. Harm}

Freedoms of individuals are modulated by harm principle. By a common sense in precedents, this principle can simply be defined as a lim-

94 Article 5(3) EC Treaty; 8/55 Fedechar, 1956, ECR 245, available at: https://eurlex.europa.eu/legal-content/EN/TXT/? uri=CELEX\%3A61955CJ0008; 22/70 Commission v. Council, 1970, ECR 263, available at: https://eur-lex.europa.eu/legal-content/EN/ TXT/? uri=CELEX\%3A61970CJ0022; C-415/93 Bosman, 1995, ECR 1-4921, available at: https://eur-lex.europa.eu/legal-content/EN/TXT/? uri=CELEX\%3A61993CJ0415.

95 For example, see Barnard v. National Dock Labour Board, 1953, 2 QB 18, available at: https://webstroke.co.uk/law/cases/barnard-v-national-dock-labour-board-1953.

96 For example, see BVerwGE 34, 278 (Germany), available at: https://dejure. org/dienste/vernetzung/rechtsprechung? Gericht $=$ BVerw G\&Datum $=10.12 .1969 \& \mathrm{~A}$ ktenzeichen=VIII\%20C\%20104.69; Case 52/81 Faust v. Commission, 1982, ECR 3745 (European Union), available at: https://eur-lex.europa.eu/legal-content/EN/ TXT/? uri=CELEX\%3A61981CJ0052; Briggs v. Elliott, 342 U.S. 350, 1952, (United States of America), available at: https://supreme.justia.com/cases/federal/us/342/350; Jones v. University of Manchester, 1993, ICR 474 (United Kingdom), available at: https://swarb.co.uk/jones-v-university-of-manchester-ca-10-mar-1993.

9775 \& 117/82 Razzouk and Beydoun, 1984, ECR 1509, available at: https://eur-lex. europa.eu/legal-content/EN/TXT/? uri=CELEX\%3A61982CJ0075.

98 C-139/95 Balestra, 1997, ECR 1-549, available at: https://eur-lex.europa.eu/legalcontent/DE/TXT/? uri $=$ CELEX\%3A61995CJ0139.

Esta obra está bajo una Licencia Creative Commons Atribución-NoComercial-SinDerivar 4.0 Internacional, IIJ-UNAM. 
itation on freedoms to prevent actions of an individual from harming others. ${ }^{99}$ In the context of modern administrative law, this principle is mainly suggested in the area of discretionary powers that significantly accentuates principles of reasonableness and proportionality. ${ }^{100}$ In public sphere, public interest mingles in the discourse of harm principle by which any harmful actions regarding to collective rights and goods is impermissible. Therefore, we are witnessing of permission of derogation from rights in emergency states; ${ }^{101}$ because all kind of emergency - that by the case threaten national security, public order or like these- are noticeably endanger public interest.

\section{G. Remedy}

As a subsequent to harm principle, obviously, principle of remedy is considered. There should be effective remedies considering legal rules regarding to any harmful act including spiritual and material compensation for the injured and recover loss incurred in cases of liability of the state. It is clear that damages to a citizen, for any reason, may be not recovered or her/ his claim on detrimental action of authority is not essentially confirmed; hence, in order to protect citizens' rights, in modern ALSs, judicial remedy as an alternative one is put to enforce. The most rampant judicial remedies are as follows: qashing order (Anfechtungsklage),${ }^{102}$ prohibitory or-

\footnotetext{
99 Raymond Pfeiffer, Ralph Forsberg, Ethics on the Job: Cases and Strategies, Cengage Learning, 2013, p. 19.

100 Hoffman, Lord, "The Influence of the European Principle of Proportionality in UK", in Evelyn (ed.), The Principle of Proportionality in the Laws of Europe, Oxford, Hart Publishing, 1999, p. 114.

101 For example, in EC see Case 11/70 Internationale Handelsgesellschaft mbH v. Einfuhr-und Vorratsstelle für Getreide, 1995, ECR 1125, available at: https://eur-lex.europa. eu/legal-content/EN/TXT/? uri=CELEX\%3A61970CJ0011. In UK, see Belize Alliance of Conservation Non-Governmental Organisations v. Department of the Environment, 2004, UKPC 6, available at: https://swarb.co.uk/belize-alliance-of-conservation-nongovernmental-organisations-v-department-of-the-environment-and-another-no-2-pc13-aug-2003; $R$ v. Secretary of State for Trade and Industry, 2000, UKHL 56, available at: https://swarb.co.uk/regina-v-secretary-of-state-for-trade-and-industry-ex-parte-eastaway-hl-8-nov-2000.

102 See Prakke, L.,Kortmann, C. A. J. M. and van den Brandhof, J. C. E., Constitutional Law of 15 EU Member States, London, Kluwer, 2004, p. 446; Steiner, Udo, "Recht der Verkehrsinfrastruktur Insbesondere der öffentlichen Straßen und Wege", in Steiner, Udo 
der (Verpflichtungsklage), ${ }^{103}$ mandatory order (Leistungsklage) ${ }^{104}$ and judicial declaration (Feststellungsklage) ${ }^{105}$ commonly in UK and german law; also in particular: injunction, ${ }^{106}$ umdeutung (Reinterpretation) ${ }^{107}$ and verfassungsbeschwerde (constitutional complaint) ${ }^{108}$ respectively in UK and german law.

\section{H. Equity}

Principle of equity is mostly reflected in UK law ${ }^{109}$ as a super principle but it is originated considering natural justice which is provided in the content of legal rules in all administrative legal orders. Equity principle gives a substantive moral dimension to legal commands and makes them flexible by values based on natural justice. This is effectively derived from six main propositions which are well described in a leading case of $R v$ Home Secretary ex $p$ Dood $y^{110}$ in UK precedent: 1) discretions should be fairly exercised; 2) standards and criterions of fairness might be changed during the

and Arndt, Hans-Wolfgang (eds.), Besonderes Verwaltungsrecht: ein Lehrbuch, Berlin, C.F. Müller, 2006, p. 577; Schwenker, Uwe, Öffentliches Baurecht in Baden-Württemberg: für Ausbildung und Praxis in der Kommunalverwaltung, Berlin, Epubli, 2013, p. 31.

103 See Gersdorf, Hubertus, Verwaltungsprozessrecht, Hamburg, C.F. Müller, 2014, p. 44; Ehlers, Dirk "Verwaltungsgerichtliche Verpflichtungsklage", in Ehlers, Dirk and Schoch, Friedrich (eds.), Rechtsschutz im Öffentlichen Recht, Berlin, Walter de Gruyter, 2009, p. 641; Bailey, S. H., Cases, Materials and Commentary on Administrative Law, London, Sweet \& Maxwell, 2005, p. 449.

104 See Webley, Lisa and Samuels, Harriet, op. cit., p. 607; Wittern, Andreas and Basslsperger, Maximilian, Verwaltungs-und Verwaltungsprozessrecht: Grundriss für Ausbildung und Praxis, Stuttgart, W. Kohlhammer Verlag, 2007, p. 231; Forsyth, Christopher and Wade, William, Administrative Law, Oxford, Oxford University Press, 2009, p. 526; Ehlers, Dirk, "Allgemeine Verwaltungsgerichtliche Leistungsklage", in Ehlers, Dirk and Schoch, Friedrich (eds.), op. cit., p.659; Lewis, Clive and Knight, Christopher, Judicial Remedies in Public Law, London, Sweet \& Maxwell, 2004, p. 232.

105 See Craig P. P., Administrative Law, London, Sweet \& Maxwell, 2003, p.779; Ehlers, Dirk, op. cit., p. 673; Borchard, Edwin Montefiore, Declaratory Judgments, The classics Us, 2013, p. 15.

106 See Cane, Peter, Administrative Tribunals and Adjudication, Oxford, Hart Publishing, 2009, p. 303; Wade, H. W., op. cit., p. 564.

107 See Brandt, Jürgen, Handbuch Verwaltungsverfahren und Verwaltungsprozess, Hamburg, C.F. Müller, 2009, p. 393.

108 See Hesse, Joachim Jens and Ellwein, Ingrid, Das Regierungssystem der Bundesrepublik Deutschland: Band 2: Materialien, Munich, Springer-Verlag, 2013, p. 582.

109 Harlow, Carol and Rawlings, Richard, op. cit., p. 575.

110 Availableat:https://www.casemine.com/judgement/uk/5a8ff8cb60d03e7f57ecd7e9.

Esta obra está bajo una Licencia Creative Commons Atribución-NoComercial-SinDerivar 4.0 Internacional, IIJ-UNAM. 
time; 3) principle of equity should not be defined as a fixed and unchangeable command to identically apply in various legal situations; 4) legal commands should be committed regarding to their directions; 5) in some situations, fairly, there might be possibility of participation by citizens who their rights and duties are or will be affected by an authority's action; 6) for this participation, citizens should be fully informed and aware of the action.

Principle of equity functions by some known legitimate maxims in UK precedent. ${ }^{111}$ This principle also leads some sub-principles regarding to trial and judicial procedure that collectively are well-known as "fair trial" principle. For example in the context of EU case law, principles of "access to the courts", 112 "an independent and impartial tribunal", ${ }_{113}$ "public hearings", ${ }^{114}$ "presumption of innocence", ${ }_{115}$ and "Fair hearing" 116 which in turn puts forward principles of "advance information", 117 "reasonable time", ${ }_{118}$ "Hearing", ${ }_{119}$ "cross-examination", ${ }^{20}$ "representation", ${ }^{121}$ "reasoning", ${ }^{122}$ "equity in arms" 123 and "non- unfair evidence", ${ }^{124}$ are of the most noteworthy instances.

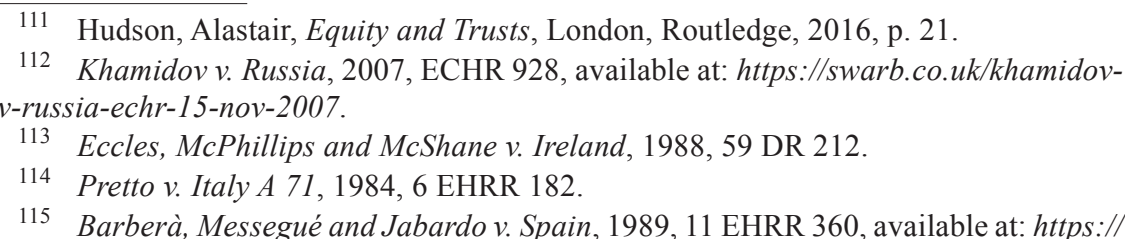
www.legal-tools.org/en/browse/record/a84e3a.

116 Available at: https://eur-lex.europa.eu/legal-content/EN/TXT/?uri=CELEX\% 3A61962CJ0032; 17/74 Transocean Marine Paint Association, 1974, ECR 1063, available at: https://eur-lex.europa.eu/legal-content/FR/TXT/? uri=CELEX\%3A61974CJ0017.

117 Rowe v. United Kingdom, 2000, 30 EHRR 1, available at: https://swarb.co.uk/ rowe-and-davis-v-the-united-kingdom-echr-16-feb-2000.

118 Galstyan v. Armenia, 2007, ECHR 936, available at: https://swarb.co.uk/galstyanv-armenia-echr-15-nov-2007.

119 Available at: http://eur-lex.europa.eu/legal-content/DE/TXT/?uri=CELEX:62011C J0679 INF.

120 Available at: http://curia.europa.eu/juris/liste.jsf?language $=$ en\&num $=C-560 / 14$.

121 Steel and Morris v. United Kingdom, 2005, ECHR 103, available at: https:// www.5rb.com/case/steel-morris-v-united-kingdom.

122 Hadjianastassiou v. Greece, 1993, 16 EHRR 219, available at: https://www.refworld.org/cases,ECHR,3ae6b6f78.html.

123 Kaufman v. Belgium, 1986, 50 DR 98, available at: http://echr.ketse.com/ doc/10938.84-en-19861209.

124 Schenk v. Switzerland, 1988, 13 EHRR 242, available at: https://swarb.co.uk/ schenk-v-switzerland-echr-12-jul-1988.

Esta obra está bajo una Licencia Creative Commons

Atribución-NoComercial-SinDerivar 4.0 Internacional, IIJ-UNAM. 


\section{Constitutional rights principles}

Each one of Constitutional rights might provide a respective principle in the context of precedent. This is customarily a german law tradition that gives a fundamental right additional legal enforcement by an identified principle in precedent. Even so, these principles could be investigated in every ALS based on constitutional rights; ${ }^{125} \mathrm{UK},{ }^{126} \mathrm{EU}^{127}$ and USA ${ }^{128}$ precedents appreciably affirm this underlying assumption. As a primary command, it is averred that individuals are free to do without any restriction except in cases where law is not allowed, democratically and legitimately. ${ }^{129}$

Hence it is very important to control government decisions as for constitutional rights in order to prevention of any unauthorized restriction on them or debarment of supernumerary duties of what is expected by laws. Apart from diversity in instances and conceptual details by a meticulous deliberation on fundamental rights in the context of each legal system, some of the most predominant constitutional rights principles are as follows: "privacy", "liberty and security", "property and possession", "religion and belief", "expression" and "assembly and association". ${ }^{130}$

125 Ray, Samirendra Nath, Judicial Review and Fundamental Rights, New Delhi, Eastern Law House, 1974, p. 32.

126 See $R$ (on the application of Saeedi) v. Secretary of State for the Home Department, 2010, EWHC 705, available at: https://www.refworld.org/cases, GBR_HC

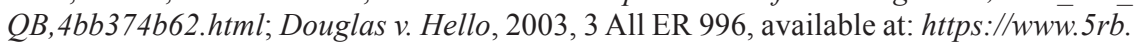
com/case/douglas-v-hello-ltd-no-5; Venables v. News group, 2001, 1 All ER 908, available at: https://www. $5 \mathrm{rb}$.com/case/venables-thompson-v-news-group-newspapers-ltd.

127 As some instances, see 29/69 Stauder v. City of Ulm, 1969, ECR 419, available at: https://eur-lex.europa.eu/legal-content/EN/TXT/?uri=CELEX\%3A61969CJ0029; 222/84 Johnston, 1986, ECR 1651, available at: https://eur-lex.europa.eu/legal-content/ EN/TXT/? uri $=$ CELEX\%3A61984CJ0222.

128 For example, see Dred Scott v. Sandford, 60 U.S. 393, 1857; Murray v. Hoboken Land, 59 U.S. 272, 1855, available at: https://supreme.justia.com/cases/federal/ us/59/272; Cohens v. Virginia, 19 U.S.264, 1821, available at: https://supreme.justia.com/ cases/federal/us/19/264.

129 Shlapentokh, Vladimir and Beasley, Eric, Restricting Freedoms: Limitations on the Individual in Contemporary America, London, Transaction Publishers, 2013, p. 3.

130 Privacy: Articles 10 and 13 of German Basic Law (Grundgesetz). For EU, see 46/87 \& 227/88 Hoechst v. Commission, 1989, ECR 2859, available at: https://supreme.justia. com/cases/federal/us/19/264; Fadeyeva v. Russia, 2005, ECHR 376, available at: https:// www.informea.org/sites/default/files/court-decisions/CASE\%20OF\%20FADEYEVA\%20 v.\%20RUSSIA.pdf. For UK, see $R$ v. Secretary of State for Health, ex parte L (M), 2001, 1 FLR 406, available at: https://www. $5 \mathrm{rb}$.com/case/r-v-secretary-of-state-for-health-ex- 


\section{MODERN PRINCIPLES}

\section{Following to good administration doctrine theorization among ALSs, judges have made a great effort to induct modern principles which strong-}

parte-associated-newspapers-others; R v. Attorney-General, 2007, UKHL 52, available at: https://publications.parliament.uk/pa/ld200708/ldjudgmt/jd071128/countr-1.htm.

Liberty and Security: Article 2 (2) of German Basic Law. for EU, see Johansen v. Norway, 1985, 44 DR 155, available at: http://co-guide.org/jurisprudence/case-johansen-v-norway-application-no-1060083; Weeks v. United Kingdom, 1988, 10 EHRR 293, available at: https://swarb.co.uk/weeks-v-the-united-kingdom-echr-2-mar-1987. For UK, see $R$ v. Parole Board, 2008, EWCA Civ 29, available at: http://www.mentalhealthlaw.co.uk/R_(Brooke)_v_Parole_Board_(2008)_EWCA_Civ_29; Girling v. Parole Board, 2005, EWHC 546, available at: https://www.casemine.com/judgement/ $u k / 5 a 8 f f 75860 d 03 e 7 f 57 e a b 85 f$.

Property adn Possession: Article 3 of German Basic Law. for EU, see Palumbo v. Italy, 1996, ECHR No.15919/89, available at: http://echr.ketse.com/doc/15919.89en-19960904; Spadea v. Italy, 1995, 21 EHRR 482, available at: https://swarb.co.uk/ spadea-and-scalabrino-v-italy-echr-28-sep-1995; and for UK, see Yanner v. Eaton, 1999, 166 ALR 258, available at: https://www.lawteacher.net/cases/yanner-v-eaton-1999.php.

Religion and Belief: Article 4 (1) of German Basic Law: for EU, see Otto Preminger Institut v. Austria, 1994, 19 EHRR 34. available at: https://swarb.co.uk/otto-preminger-institutv-austria-echr-20-sep-1994; Autio v. Finland, 1991, 72 DR 245, available at: https://www. wri-irg.org/en/story/1991/case-tomi-autio-v-finland-1708690-inadmissibility-decision; and for UK, see $R v$. Secretary of State for Education and Employment, 2005, UKHL 15, available at: https://publications.parliament.uk/pa/ld200405/ldjudgmt/jd050224/will-1.htm.

Expression: Article 5 (1) of German Basic Law: for EU, see Ukrainian Media Group v. Ukraine, 2005, ECHR 198, available at https://www.legal-tools.org/en/browse/ record/34f2bb; for UK, see Cf Wheeler v. Leicester City Council, 1985, AC 1054, available at: https://swarb.co.uk/wheeler-v-leicester-city-council-in-re-wheelerand-others-hl-25-jul-1985; $R$ v. Barnet Council, ex p Johnson, 1991, 89 LGR 581, available at: https://swarb.co.uk/regina-v-barnet-london-borough-council-ex-parteshah-hl-16-dec-1982; Rushbridger v. Attorney-General, 2003, UKHL 38, available at: https://publications.parliament.uk/pa/ld200203/ldjudgmt/jd030626/rus-1.htm.

Assembly and Association: Articles 9 and 10 of German Basic Law: for EU, see $G v$. Federal Republic of Germany, 1989, 60 DR 256, available at: https://publications.parliament.uk/pa/ld200506/ldjudgmt/jd051027/gold-3.htm; Bukta v. Hungary, 2007, ECHR 610, available at: https://www.legislationline.org/documents/id/17932; Vogt v. Germany, 1996, 2 EHRR 205, available at: https://swarb.co.uk/vogt-v-germany-echr-1-nov-1995; Associated Society of Locomotive Engineers and Firemen v. United Kingdom, 2007, ECHR 184, available at: https://swarb.co.uk/associated-society-of-locomotive-engineers-andfiremen-v-lee-eat-23-feb-2004; for UK, see R v. Attorney-General, 2007, UKHL 52, available at: https://swarb.co.uk/countryside-alliance-and-others-regina-on-the-application-of-v-attorney-general-and-another-hl-28-nov-2007; $R$ v. Chief Constable, 2007, AC 105, available at: https://www.5rb.com/case/r-laporte-v-chief-constable-of-gloucestershire.

Esta obra está bajo una Licencia Creative Commons

Atribución-NoComercial-SinDerivar 4.0 Internacional, IIJ-UNAM. 
ly hold good administration values in their discourses. The clear example of effect of this doctrine can be found in article 41 of European Charter of Fundamental Rights. Some scholars believe that good administration is essentially a GPAL that fills the legal vacuum relating to administrative law and also empowers a substantive dimension of the rule of law; in opposition, there are scholars who defend of counting good administration as a fundamental right. ${ }^{131}$ Howsoever, it could be deduced that good administration specifies the path and is realized by modern principles which are thoroughly applied in ALS. In most of cases following instances can be reckoned with as modern principles that forcefully instate good administration in ALS: legitimate expectations, reasonableness, relevant considerations, proportionality, time limits, transparency, accountability, abuse of power, impartiality, public participation, responsiveness, unfettered discretion and proper purpose.

\section{Legitimate expectations}

Authorities are required to protect a citizen's legitimate expectations that they themselves have caused them. This could be result of announcements, regulations, procedures, measures, and even promises made to citizens; in a way that people, by trusting to the situations and subsequences, rely their personal and commercial life on. Decisions based on such qualifications should be subject to procedural fairness that require a convincible degree of legal protection and should not be outside the scope of equity and justice. ${ }^{132}$ This is the general broad concept of legitimate expectations principle is common in EU, UK and german law. ${ }^{133}$

131 Azoulay, Loïc, "The Judge and the Community's Administrative Governance", in Joerges, Christian and Dehousse, Renaud (eds.), Good Governance in Europe's Integrated Market, Oxford University Press, Oxford, 2002, p. 109; Nehl, Hanns Peter, "Good Administration as Procedural Right and/or General Principle?", in Hofmann, Herwig and Alexander Türk, Legal Challenges in EU Administrative Law: Towards an Integrated Administration, Cheltenham, Edward Elgar Publishing, 2009, p. 322; Ponce Solé, J., "Good Administration and European Public Law: the Fight for Quality in the Field of Administrative Decisions", European Review of Public Law, vol. 14, No. 4, 2002, p. 1503.

132 Robert, Thomas, Legitimate Expectations and Proportionality in Administrative Law, Oxford, Hart Publishing, 2000, p. 41.

${ }^{133}$ For UK, see Schmidt v. Secretary of State for Home Affairs, 1969, available at: https://swarb.co.uk/schmidt-and-another-v-secretary-of-state-for-home-affairs-ca- 
Based on UK precedent, generally, in four situations legitimate expectations are protected under the law: 1) revocation of decision: ${ }^{134}$ when a public authority adopts a decision, it may affect citizens' rights and privileges in such a way that creates new status which are eventuated and subordinated of that; that's while, the previous decision is replaced by a new superseded one, which subsequently mutates the status and influences those rights and privileges in a different way; 2) breach of assurance: ${ }^{135}$ in some cases, the public authority may commit to make certain policies and processes to a specific matter, but in contrast to this, she/he act differently and thereby changes the statu quo. 3 ) change of consistent practice: ${ }^{136}$ in such cases, the public authority, without be committed to make certain policies and processes, over a long period of time, uniformly acts in the same way somehow citizens suppose that the status quo will always be established and stable; that's while, this will all change as a result of her/his new decision by adopting a superseded different policies and processes; 4) change of policy: ${ }^{137}$ a public official promise to act on a particular policy or process in relation to upcoming stages by a specific issue and citizens would also expect the action to be taken, but at the appropriate time, the authority will act differently.

19-dec-1968; Regina v. Secretary of State for the Home Department (Appellant) ex parte Uttley (Respondent), 2004, available at: https://publications.parliament.uk/pa/ld200304/ ldjudgmt/jd040722/uttley-4.htm. And for EU, see Case T-347/03 Branco v. Commission, 2005, ECR II-255, available at: http://curia.europa.eu/juris/showPdf.jsf;jsessionid=9ea 7d2dc30d551273c1bb61d4e46b276ca549987da33.e34KaxiLc3qMb40Rch0SaxuObN50 $?$ docid $=57964 \&$ pageIndex $=0 \&$ doclang $=E N \&$ dir $=\& o c c=$ first $\&$ part $=1 \&$ cid $=1006476$; Case 265/85 van den Bergh en Jurgen v. Commission, 1987, ECR 1155, available at: https:/leur-lex.europa.eu/legal-content/EN/TXT/? uri=CELEX\%3A61985CJ0265. Also, for GL see 9 BVerwGE 251.

134 Rootkin v. Kent CC, 1981, 2 All ER 227.

135 A-G of Hong Kong v. Ng Yuen Shiu, 1983, AC 629, 638, available at: $R$ v. IRC, ex p MFK Ltd, 1990, 1 All ER 91, 110.

136 Council of Civil Service Unions v. Minister for the Civil Service, 1985, AC 375, available at: https://swarb.co.uk/council-for-civil-service-unions-v-minister-for-the-civil -service-hl-22-nov-1984; $R$ v. Home Secretary, 2005, EWCA Civ 744, available at: http:// uniset.ca/other/cs6/brianhaw.html.

$137 R$ v. Health Secretary, ex p US Tobacco International Inc, 1992, QB 353, available at: https://swarb.co.uk/regina-v-secretary-of-state-for-health-ex-parte-united-states-tobacco-international-inc-ca-1991; $R$ v. North and East Devon Health Authority, ex p Coughlan, 2001, QB 213, available at: https://swarb.co.uk/regina-v-north-and-eastdevon-health-authority-ex-parte-coughlan-and-secretary-of-state-for-health-intervenorand-royal-college-of-nursing-intervenor-ca-16-jul-1999.

Esta obra está bajo una Licencia Creative Commons

Atribución-NoComercial-SinDerivar 4.0 Internacional, IIJ-UNAM. 
Legitimate expectations principle (Vertrauensschutz) in german law has got the similar concept as we might apperceive from articles 20 and 28 of basic law and also in the context of some known cases. For example in Widow $w^{138}$ case, the judge put forward two situations in which citizens' legitimate expectations are under protection: when government has adopted a regulation in contravention of the law or committed an illegal act, but its effects remain valid for a while and then it is nulled and voided; moreover, in any situation in which some particular sort of privileges or benefits be permanently conferred upon citizen by an official decision but after a while ordered to be suspended.

\section{Reasonableness}

Always, there must be a reasonable relationship and logical connection between the decision taken by an authority and the objectives on which it was based in the content of legal commands. ${ }^{139}$ In general words, authorities are supposed to make decision in a rational way. The principle of reasonableness, which is closely linked to modern legal principles, in many cases of UK precedent is taken against government decisions. ${ }^{140}$ There are plural cases in UK and EU precedents in which principle of reasonableness is inextricably interconnected with principles of effectiveness and relevant considerations; however, it doesn't mean that they equally imply an exact meaning. ${ }^{141}$ This

\footnotetext{
1389 BVerwGE 251.

139 Bongiovanni, Giorgio; Sartor Giovanni and Valentini Chiara, op. cit., pp. 5-7.

140 For example: Canadian Association of industrial, Mechanical and Allied Workers,
} Local 14 v. Paccar of. Canada Ltd., 1989, available at: https://scc-csc.lexum.com/scccsc/scc-csc/en/item/532/index.do; R. v. Secretary of State for the Environment, Transport and the Regions, 2001, available at: https://www.emeraldinsight.com/doi/abs/10.1108/ eb025081; Phalam Gurung v. Ministry of Defence, 2002, EWHC 2463, available at: https:// swarb.co.uk/gurung-pun-and-thapa-v-ministry-of-defence-qbd-27-nov-2002. $R$ v. Swindon NHS Primary Care Trust, 2006, EWCA Civ 392, available at: https://swarb.co.uk/rogersregina-on-the-application-of-v-swindon-nhs-primary-care-trust-ca-12-apr-2006.

141 Barbier de la Serre, Eric, "Procedural Justice in the European Community Case-law Concerning the Rights of the Defence: Essentialist and Instrumental Trends", European Public Law review, vol. 12, No. 2, 2006, p. 225; Galligan, Denis James, Due Process and Fair Procedures: A Study of Administrative Procedures, Oxford, Clarendon Press: 1996, p. 128; Mashaw, Jerry L., Due Process in the Administrative State, California, Yale University Press, 1985, p. 104; Tribe, Laurence H., American Constitutional Law, New York, Foundation Press, 1978, p. 666. 
principle, as a well-known GPAL in german law, ${ }^{142}$ gives rise to a form of social acceptance of government activity, which typically aligns administrative performance with society rationality. ${ }^{143}$ Unreasonableness of an authority's decision or measure is some kind of action that individuals do not rationally and logically deal with it; ${ }^{144}$ such actions clearly lack a rational argument or ethical standards which confirm merit of it. ${ }^{145}$ Unreasonable action is like a retrogressive decision or measure which not only does not conduct ALS to progress, but actually leads it to reversal quality of the statu quo.

Invalidation of some kind of unreasonable actions is only possible that apparently and to a large extent have an irrational nature which is seriously in conflict with legitimacy. Therefore, any action cannot be simply counted as an unreasonable one to void. ${ }^{146}$ Effectiveness and efficiency might be one of good evaluation criteria for reasonableness of an action. A decision or measure that does not efficient or does not bring forth a significant positive effect on the public interest is not fundamentally rational and more likely to cause loss of public resources are available. Essentially, good administration requires that processes and institutions work in line with needs of society and make the best possible use of resources. ${ }^{147}$

142 Schoch, Friedrich, "Der Verfahrensgedanke im Allgemeinen Verwaltungsrecht", Die Verwaltung, vol. 25, 1992, p. 21.

143 Würtenberger, Thomas, "Akzeptanz durch Verwaltungsverfahren”, NJW, 1991, p. 257; Schmitt Glaeser, Walter, "Die Position der Bürger als Beteiligte im Entscheidungsverfahren gestaltender Verwaltung", in Lerche, P.; Schmitt Glaeser, W. and SchmidtAßmann, E. (eds.), Verfahren als Staats- und Verwaltungsrechtliche Kategorie, Heidelberg, 1984 , p. 35.

144 Education Secretary v Tameside Council, 1977, AC 1014 at 1064, available at: https://swarb.co.uk/secretary-of-state-for-education-and-science-v-tameside-metropolitan-borough-council-hl-21-oct-1976.

145 Council of Civil Service Unions v Minister for the Civil Service, 1985, AC 374, 410, available at: https://webstroke.co.uk/law/cases/council-of-cvil-service-unions-vminister-for-the-civil-service-1985.

146 See $R$ v Home Secretary, 2001, UKHL 26, [2001] 2 AC 532, available at: https:// publications.parliament.uk/pa/ld200001/ldjudgmt/jd010523/daly-1.htm.

147 Scheb, John, Law and the Administrative Process, London, Cengage Learning, 2004, p. 17.

Esta obra está bajo una Licencia Creative Commons

Atribución-NoComercial-SinDerivar 4.0 Internacional, IIJ-UNAM. 


\section{Relevant considerations}

As stated above, one of principles related to reasonableness is relevant considerations; and this is why in many cases judges state that when a decision is made and considerations related to the subject of it are not considered, this decision cannot be a rational one. ${ }^{148}$ When discretions are provided by law to public official, in fact, they are required to do so in an appropriate and the most possible worthy manner; hence, failure to take into account the relevant and vital involved components of the decision is negligence in fulfilling the obligation. In UK, lack of attention to determinant considerations of an administrative decision is remarked to be a factor in voidance and legally invalidation. ${ }^{149}$ In accordance with EU precedent, the principle requires not only that administrative authorities should collect and pay attention to relevant considerations and related issues of their decision, but also obliges them to address all reasonable aspects of the matter in his actions; in order to adhering probable subordinate subsequences with legal norms. ${ }^{150}$ This, in particular, extends the path to realization of accuracy principle, which is typically tied to principle of relevant considerations.

Accuracy means concentration of mind relating to a given subject and paying close attention to it. According to principle of "accuracy", a public authority should make a decision with specific obsession and scrutiny

148 Minister for Aboriginal Affairs v Peko-Wallsend Ltd, 1986, available at: https:// jade.io/summary/mnc/1986/HCA/40; $R$ v. Secretary of State for the Home Department, ex parte Findlay, 1985, AC 318, available at: https://swarb.co.uk/regina-v-secretary-ofstate-for-the-home-department-ex-parte-hindley-hl-30-mar-2000/.

${ }_{149} R$ v. Somerset County Council, ex parte Fewings and others, 1995, available at: https://swarb.co.uk/regina-v-somerset-county-council-ex-parte-fewings-and-others-ca-22-mar-1995; Regina v. Gloucestershire County Council, ex parte Barry, 1997, available at: https://swarb.co.uk/regina-v-gloucestershire-county-counciland-another-ex-parte-barry-hl-21-mar-1997; $R$ v. Home Secretary, ex p Venables, 1998, AC 407, available at: http://uniset.ca/other/cs5/1998AC407.html; $R$ v. Newham London Borough Council, ex parte Sacupima, 2004, available at: https://swarb. co.uk/regina-v-newham-london-borough-council-ex-parte-sacupima-and-othersca-1-dec-2000.

${ }^{150}$ Case 34/77. Josef Oslizlok v. Commission, 1978, ECR 1099, available at: https://eur-lex.europa.eu/legal-content/EN/TXT/? uri=CELEX\%3 A61977CJ0034. Case C-269/90, Technische Universität München v. Hauptzollamt München-Mitte, 1991, ECR I-5469, available at: https://eur-lex.europa.eu/legal-content/en/ TXT/? uri $=$ CELEX\%3A61990CJ0269. 
about its relevant facts and norms; ${ }^{151}$ this means that all details and aspects of the matter should be investigated and analyzed. In any case, principle of relevant considerations and principle of accuracy are two sides of a coin, together emphasize inclusion of facts and norms and considering their involved components in decision; hence, in most of cases, they strengthen principle of reasonableness. ${ }^{152}$ Principle of relevant considerations and accuracy do not merely emphasize attention and consideration of issues, but by its negative sense, authority is obliged to do not consider irrelevant considerations or slight importance to the decision; ${ }^{153}$ this command prevents spending time and money in improper way and hence, empowers principles of reasonableness and time limits.

\section{Proportionality}

According to this principle, there must be a reasonable appropriateness between a decision made by an authority and objectives on which it is legally based. ${ }^{154}$ Three main criterions might be considered for appraisement of this proportionality: sufficiency, necessity and appropriateness. ${ }^{155}$ Potency of an action to achieve the most desired goal of discretion, can imply its sufficiency; if there is no other suitable alternative action, or probably is

151 Case T-147/97 Champion Stationery Mfg Co. Ltd, Sun Kwong Metal Manufacturer Co. Ltd and US Ring Binder Corporation v Council of the European Union, 1998, ECR II-4137, available at: https://eur-lex.europa.eu/legal-content/EN/ TXT/? uri=CELEX\%3A61997TJ0147; C-194/99 Thyssen Stahl AG v Commission of the European Communities, 2003, ECR I-10821, available at: https://eur-lex.europa.eu/legal-content/GA/TXT/? uri=CELEX:61999CJ0194.

152 Tridimas, Takis, The General Principles of EU Law, Oxford University Press, Oxford, 2013, pp. 391 y 392.

153 See $R$ v. Port Talbot Council, ex p Jones, 1988, 2 All ER 207, available at: https:// $w w w$.lawteacher.net/free-law-essays/judicial-law/action-based-on-judicial-review.php; $R v$. Tower Hamlets Council, ex p Chetnik Developments Ltd, 1988, AC 858, available at: https://swarb.co.uk/regina-v-tower-hamlets-london-borough-council-ex-parte-chetnikdevelopments-limited-hl-1988; Mixnam's Properties Ltdv Chertsey UDC, 1965, AC 735, available at: https://swarb.co.uk/mixnams-properties-ltd-v-chertsey-urban-district-council-hl-1965.

154 Andreescu, M., "Principle of Proportionality, Criterion of Legitimacy in the Public Law", Lex et Scientia Juridical Series, vol. 1, 2001, p. 117.

155 Cohn, Margit "Three Aspects of Proportionality", Conference Review: 8th World Congress of the International Association of Constitutional Law (IACL), 2010, p. 4.

Esta obra está bajo una Licencia Creative Commons

Atribución-NoComercial-SinDerivar 4.0 Internacional, IIJ-UNAM. 
less important than that decision, necessity is evident; in addition, in order to justifying appropriateness of the decision taken, its resulted benefits should overcome injuries and disadvantages one. Proportionality principle strongly empowers the rule of law and constitutional rights as it is obvious in $\mathrm{UK},{ }^{156} \mathrm{EU}^{157}$ and German precedents. ${ }^{158}$ One of the most leading descriptive propositions of the principle that is well reflected in article 5 (4) of the EU Treaty is balance maintenance requisite of decision; accordingly, the actions taken in relation to each issue should not exceed of extreme or least rational appropriateness; for instance, appropriateness of authority's decision with goals based on the spirit of law ${ }^{159}$ or appropriateness between an administrative actions and a fundamental right's requisites and objective ${ }^{160}$ or appropriateness of imposing conditions to citizens' rights and what is rationally apperceived by regulations. ${ }^{161}$

\section{Time limits}

In the direction of public service, time limits principle implies that there should be reasonable time during decision-making and respective measure by authority. ${ }^{162}$ For any discretion assigned to government officials there is reasonable time limit to exercise; so postponement and delay in carrying out appropriate action violates this principle. ${ }^{163}$ Hence, the principle might be

$156 R v$ Secretary of State for the Home Department, ex parte Brind, 1991, 1 AC 696, available at: https://swarb.co.uk/regina-v-secretary-of-state-for-the-home-departmentex-parte-brind-hl-7-feb-1991; Association of British Civilian Internees-Far East Region v. Secretary of State for Defence, 2003, EWCA Civ 473, available at: https://swarb.co.uk/ the-association-of-british-civilian-internees-far-eastern-region-abcifer-v-secretary-ofstate-for-defence-ca-3-apr-2003.

157 Bowman v. United Kingdom, 1998, ECHR 4, available at: http://www.hrcr.org/safricalexpression/bowman_uk.html.

158 BVerfGE 23,127 (133); BVerfGE 23, 127 (133); BverfGE 69, 1 (35); BVerfGE 61, 126 (134).

$159 R v$ Secretary of State for the Home Department, ex parte Brind, cit.; Association of British Civilian Internees-Far East Region v. Secretary of State for Defence, cit.

160 Bowman v. United Kingdom, cit.

161 BverwG, NJW 1995, 3334.

162 Hofmann, Herwig C. H.; Rowe, Gerard C. and Türk, Alexander H., op. cit., p. 196.

163 O'Reilly, Ex parte Australena Investments, 1983, 58 ALJR 36, available at: https://iknow.cch.com.au/document/atagUio549431sl16838105/re-o-reilly-ex-parteaustralena-investments-pty-ltd-ors; Charles v. Judicial and Legal Service Commis- 
called "reasonable period of time" like what is common in EU precedent. ${ }^{164}$ The principle requires that all administrative processes, as well as addressing citizens' demands or pure intra-organizational operations, should be carried out in the shortest and fastest possible time. Along with time limits, principle of "continuity", that is mostly prevalent in French administrative law, implies that state services should be constantly provided for citizens; based on French precedent, since all citizens equally take advantage of state-owned public services, activities of public officials and institutions should not be interrupted and they should avoid any action that would delay or causes public services closure. ${ }^{165}$

\section{Transparency}

This principle has been recognized in order to guarantee freedom of information and realization of public monitoring over government's actions. Principle of transparency, through strengthening a clear administrative system and possibility of public oversight, aids in realization of the rule of law. ${ }^{166}$ In accordance with principle of transparency, all decisions, measures, transactions, agreements and all administrative processes documents should be available to access for all citizens as direct beneficiaries. ${ }^{167}$ Due

sion and another, 2002, UKPC 34, available at: https://www.casemine.com/judgement/ in/5779fbfae561096c93131992.

164 Case T-344/00 CEVA and Pharmacia entreprises $v$ Commission, 2003, ECR II229, available at: https://eur-lex.europa.eu/legal-content/EN/TXT/PDF/? uri=CELEX: 62000TJ0344_SUM\&from $=E L$; Case C-501/00 Kingdom of Spain v. Commission, 2004, ECR I-6717, available at: http://curia.europa.eu/juris/liste. jsf?language $=e n \& j u r=C, T, F \&$ num $=C-501 / 00 \& t d=A L L ;$ Case $\mathrm{T}-204 / 03$ Haladjian Frères SA v. Commission, 2006, ECR II-3779, available at: http://curia.europa.eu/juris/ showPdf.jsf;jsessionid $=9$ ea $7 d 0 f 130 d e 4216 b d 66310 e 4 e 2 \mathrm{cbld} 7 f 50 d 15 \mathrm{cbd} 941 . e 34 \mathrm{KaxiL}$ c3eQc40LaxqMbN4Ob34Pe0 $?$ docid $=63533 \&$ pageIndex $=0 \&$ doclang $=E N \&$ mode $=\&$ dir $=\& o c c=$ first $\&$ part $=1 \&$ cid $=37156$.

165 Conseil d'Etat, 5 November 1982, available at: https://www.legifrance.gouv.fr/affichJuriAdmin.do? oldAction $=$ rechJuriAdmin\&idTexte $=$ CETATEXT000007686895\& fast ReqId=1537965912\&fastPos $=1$. Conseil d'Etat, 9 December 1988, available at: https:// www.legifrance.gouv.fr/affichJuriAdmin.do?idTexte $=$ CETATEXT000007749908.

166 Hofmann, Herwig C. H.; Rowe, Gerard C. and Türk, Alexander H., op. cit., p. 170.

167 Curtin, Deirdre and Wessel, Ramses A., Good Governance and the European Union: Reflections on Concepts, Institutions and Substance, New York, Intersentia nv, 2005, p. 39.

Esta obra está bajo una Licencia Creative Commons

Atribución-NoComercial-SinDerivar 4.0 Internacional, IIJ-UNAM. 
to information technology system development, this principle has also grown abundantly; this is mainly resulted by rapidity of information transmission by possible means of quick disseminating and expediting access possibility to them for all. Therefore, the most important components of the principle are freedom of information and IT (information technology), which is very much emphasized in EU precedent. ${ }^{168}$ One worthy imperative derivatives could be public procurement and tenders-bidding rectitude by three general mechanisms for realization of the principle: periodic indicative notices, invitation to tenders and contract award notice. ${ }^{169} \mathrm{Of}$ course, the principle is not absolute and in certain legal situations exceptions have been made. For example, in UK, non-disclosure of confidential secrets and documents is a clear exception of the principle. ${ }^{170}$

\section{Accountability}

Accountability is one of democracy foundations. In fact, peoples have entrusted government agents as their representations with the task of exercising the power for public interest; hence, they should respond about their actions to these real owners of the power; ${ }^{171}$ otherwise, it will establish a tyranny of power. ${ }^{172}$ This principle, by standing in the line with principles of transparency and legality, obliges public authority to make decisions in a transparent system and to be accountable about any action on demand of citizens including legitimately justification and legally

168 Case T-105/95 WWF UK v Commission, 1997, ECR II-313, available at: http:// curia.europa.eu/juris/liste.jsf?language $=$ en $\&$ jur $=C, T, F \& n u m=T-105 / 95 \& t d=A L L$; Case T-188/97 Rothmans International BV (supported by Sweden) v European Commission, 1999, ECR II-2463, available at: https://eur-lex.europa.eu/legal-content/EN/ TXT/? uri=CELEX\%3A61997TJ0188; Case C-345/06 Heinrich, 2009, ECR I-1659, available at: http://curia.europa.eu/juris/liste.jsf?language $=e n \& n u m=C-345 / 06$.

169 Bovis, H. Christopher, "The Effects of the Principles of Transparency and Accountability on Public Procurement", in Hofmann, Herwig and Türk, Alexander (eds.), Legal Challenges in EU Administrative..., cit., p. 288.

170 Wv. Egdell, 1990, 1 All ER 835, available at: http://www.globalhealthrights.org/ wp-content/uploads/2013/03/EWCA-1989-W-v.-Egdell.pdf.

171 Bamforth, Nicholas and Leyland, Peter, Accountability in the Contemporary Constitution, Oxford, Oxford University Press, 2013, p. 30.

172 Matei, Lucica; Vašiček, Davor and Kaštelan-Mrak, Marija, European Administrative Space.Balkan Realities, 2011, p. 215.

Esta obra está bajo una Licencia Creative Commons Atribución-NoComercial-SinDerivar 4.0 Internacional, IIJ-UNAM. 
documentation; this is the main face of EU accountability we are confronting with. ${ }^{173}$

Although the principle is one of the main elements of good administration, but UK has not fully recognized it in judicial practice. In other words, in the legal system of this country, there are no legal requirements for providing or presentation of reasons and documentation about any government actions, if there would be a citizen's demand; except in special cases that accountability is obviously required by law. ${ }^{174}$ For example, accountability of UK's administrative tribunals to respond about their decision to parties of any complaint. ${ }^{175}$ But in german law the principle requires government, in many cases, to provide an appropriate response for each of its actions; including clause of "reason giving" (Begründung) in article 39 of the German Administrative Procedure Act (Verwaltungsverfahrensgesetz) that requires regulations to be accompanied with legal and practical reasons and considerations. In addition, all decisions made by government authorities in cases of discretionary power should be based on clear and substantiated legal and technical grounds, as appropriate, to explain. In german law, giving reasons is indispensable for public monitoring in addition to resolve potential complaint by clarifying actions and convincing citizens. ${ }^{176}$

\section{Abuse of power}

It has been argued earlier that, with emphasis on modern administrative law along with substantive legality in ALS, prohibition of abuse of power has been found as an essential aspect of the rule of law; that's why EU judges have emphasized inhibition of personal interest in exercising discretions. ${ }^{177}$ According to considerable latitude of authority by exercising

173 Hofmann, Herwig C. H.; Schneider, Jens-Peter and Ziller, Jacques (eds.), op. cit.

174 See Public Service Board of New South Wales v Ormond, 1986, 63 ALR 559, available at: https://jade.io/summary/mnc/1986/HCA/7; R v. Trade Secretary, ex p Lonrho plc, 1989, 2 All ER 609, available at: https://shu.rl.talis.com/items/DA94AAB5-56D8-3B5C9A4C-05E1E20D6946.html; $R$ v. Higher Education Funding Council, ex p Institute of Dental Surgery, 1994, 1 All ER 651, available at: https://webstroke.co.uk/law/cases/r-vhigher-education-funding-council-ex-p-institute-of-dental-surgery-1994.

175 Article 10, Tribunals \& Inquiries Act 1992.

176 Badura, Peter and Erichsen, Hans-Uwe, Allgemeines Verwaltungsrecht, Berlin, V. W. de Gruyter, 1988, p. 418.

177 Case 4/64 Chambre Syndicale de la Siderurgie Francaise, 1965, ECR 441, available 
given discretion, it is always intimidated that they would engage their personal interests in their decisions or give priority to specific group interests while collective interest is neglected; ${ }^{178}$ for this reason, principle of abuse of power has been identified among judges to put authorities' decisions under substantive review. This illustrate the reason that why UK precedent has prohibited applying power for personal gain, in conflict with the spirit of law ${ }^{179}$ or do not adhering to goal of law and serving commitment to citizens. ${ }^{180}$

\section{Impartiality}

According to conseil d'Etat, neutrality is incumbent and decisive for correctness of government's decisions and measures in light of legality; otherwise, it could lead to discrimination and violating principle of equality. ${ }^{181}$ This has been raised in UK by prohibiting all forms of discrimination and discriminatory provision of public services, ${ }^{182}$ particularly in public procurement such as in

at: https://eur-lex.europa.eu/legal-content/FR/TXT/?uri=CELEX\%3A61964CJ0003. Case C-222/84, Johnston v Chief Constable, RUC, 1987, QB 129, available at: http://curia. europa.eu/juris/showPdf.jsf;jsessionid $=3$ D664827B949AC45123B703E80D6D58B?text $=\&$ docid $=93569 \&$ pageIndex $=0 \&$ doclang $=e n \&$ mode $=r e q \&$ dir $=\& o c c=$ first $\&$ part $=1 \& c$ $i d=10161507$.

178 Schwartz, Bernard, French Administrative Law and the Common-Law World, The Lawbook Exchange, Ltd., 1954, p. 216.

179 Associated Provincial Picture Houses Ltd. v. Wednesbury Corporation, 1948, 1 KB 223, available at: https://lawcasesummaries.com/knowledge-base/associated-provincialpicture-houses-ltd-v-wednesbury-corporation-1948-1-kb-223; $R$ v. Inland Revenue Commissioners, ex p National Federation of Self-employed and Small Businesses Ltd, 1982, AC 617, available at: https://swarb.co.uk/regina-v-inland-revenue-commissioners-exparte-the-national-federation-of-self-employed-and-small-businesses-ltd-hl-9-apr-1981; $R$ v. Environment Secretary, ex p Nottinghamshire County Council, 1986, AC 240, available at: https://swarb.co.uk/regina-v-secretary-of-state-for-the-environment-ex-partenottinghamshire-county-council-hl-12-dec-1985.

$180 R v$. Secretary of State for Employment, ex parte begble, 2000, 1 WLR 1115, available at: https://swarb.co.uk/regina-v-department-of-education-and-employment-ex-parte-begbie-ca-20-aug-1999.

181 Conseil d'Etat, 28 January 1948. Conseil d'Etat, 4 March 1949.

$182 R$ v. Hendon Rural District Council, ex parte Chorley, 1933, 2 KB 696, available at: https://www.coursehero.com/file/p5o9nf5/R-V-Hendon-Rural-District-Council-ex-parteChorley-1933-2KB-696-1-In-this-case. 
tendering procedures. ${ }^{183}$ In fact, principle of equality and government accountability to provide public interest constitute impartiality principle existential philosophy. For this reason, the principle is one of necessary and indispensable fundamental norms of good administration in EU ALS. ${ }^{184}$

\section{Public participation}

Governmentality and democracy in the context of post-modern ALSs, ${ }^{185}$ especially in post-regulatory states ${ }^{186}$, are prime corollaries of public participation. Citizens could participate directly, personally or through legitimate institutions, or indirectly by their elected representatives. However, it should be noted that establishment of democracy does not necessarily mean that expectations of vulnerable sectors should be involved in adoption of policies, but that participation must be organized and implemented through clear effective means which was probably defined. ${ }^{187}$ Participation principle mainly requires protection of freedoms of association and expression, on the one hand, and organizing civil society, on the other hand. Extension of this principle comes to privatization which is widely observed in regulatory states as a main political element. ${ }^{188}$ Since regulatory states are increasingly emphasizing privatization and contribution of people in administrating community affairs, role of participation principle is very efficacious and

${ }^{183} R$ v. Bow Street Stipendiary Magistrate, ex parte Pinochet Ugarte, 1999, 1 All ER 577, available at: https://swarb.co.uk/regina-v-bow-street-metropolitan-stipendiarymagistrate-ex-parte-pinochet-ugarte-no-2-hl-15-jan-1999.

184 Case C-170/02 P-Schlüsselverlag J.S. Moser and Others v. Commission, 2003, ECR I-9889, available at: http://curia.europa.eu/juris/showPdf.jsf;jsessionid=9ea $7 d 2 d$ c30dd7dbdd75446dd425e8ddb9dcfeb4b2839.e34KaxiLc3qMb40Rch0SaxqTbN10?text $=\&$ docid $=71284 \&$ pageIndex $=0 \&$ doclang $=E N \&$ mode $=r e q \&$ dir $=\& o c c=$ first $\&$ part $=1 \&$ cid=48310; Case T-395/04 Air One v. Commission, 2006, ECR II-1343, available at: https://eur-lex.europa.eu/legal-content/EN/TXT/? uri=CELEX:62004TJ0395.

185 Petoft, Arian and Vijeh, Mohammadreza, "A Foucauldian Analysis of Post-Modern Concept of Sovereignty in the Light of Public Law", Journal of Public Law Research, vol. 18 , No. 52, 2016, p. 9.

186 Petoft, Arian and Vijeh, Mohammadreza, "The Evolution of Government Intervention in the Economy from the Perspective of Public Law, Welfare to Post Regulatory Governments", The Quarterly Journal of Public Law Research, vol. 17, No. 47, 2015, p. 185.

187 Rose-Ackerman, Susan and Lindseth, Peter L., op. cit., p. 357.

188 Veggeland, Noralv, Taming the Regulatory State: Politics and Ethics, Cheltenham, Edward Elgar Publishing, 2009, p. 13. 
pivotal in such legal systems. For example, in the US legal system, which is widely applying post-regulatory states based on governmentality doctrine, judges have strongly emphasized the principle. ${ }^{189}$

Participation principle does not merely imply permission of citizens' activity in market or recognition of competency for administrating affairs to them as a hand of government, but in a sense, it defines as a main method for integrating and sharing the wisdom of people and state into a whole. That is why, along with this principle, consensus-orientation of administration is proposed. Obviously, at the society level, there are different people with different points of view, but it is mostly possible to gather minds and reach to an appropriate intellectual model which can be very fruitful for augmenting the wisdom of state. ${ }^{190}$ Good administration requires summing-up of views and resources at the community level in order to reach a broad consensus in society due to political values, goodness and proper requirements for whole of it. ${ }^{191}$ Modern administrative law is essentially diverted from the idea of "to be administrated" or "passive role of citizens", and, relying on participation principle, is directed to "administrating" ideology and "active citizens". ${ }^{192}$ Such an active role of citizens could legitimize government's wisdom in decision making and administrative actions. ${ }^{193}$

\section{Responsiveness}

The qualitative criterion of principle of exercising discretion is held forth by principle of responsiveness. In such cases, an authority has not

\footnotetext{
189 As a note-worthy one, see Hanover Potato Products Inc v. E Shalala, 989 F.2d 123, 1993.
}

190 Hartnett, Tim, Consensus-Oriented Decision-Making: the CODM Model for Facilitating Groups to Widespread Agreement, Canada, New Society Publishers, 2013, p. 1.

191 Cox, Peter, "Gradhian Values and Post-Development: Models for Social Transformation" in Ghosh, Robin (ed.), Development Studies, New Dehli, Atlantic Publishers, p. 150.

192 See Tribe, Laurence H., op. cit., p. 666; Hilf, G. Ciesla and Pache, E., "Rights vis-à-vis the Administration at the Community Level", in Cassese, A.; Clapham, A. and Weiler, J. H. H. (eds.), European Community: Methods of Protection, Baden-Baden, Nomos, 1991, p. 455; Mendes, Joana, "Participation and Participation Rights in EU Law and Governance", in Hofmann, Herwig and Alexander Türk (eds.), op. cit.

193 Röhl, K. F. "Verfahrensgerechtigkeit (Procedural Justice) Einführung in den Themenbereich und Überblick", Zeitschrift für Rechtssoziologie, vol. 14, No. 1, 1993, p. 19. 
avoided doing his legal tasks and in general has not exceeded of competency boundaries; nor was it an error of fact or law and an abuse of power; but, actually, breach of responsiveness principle is about malfunctions and negligence of duties, which has somehow reduced the quality of public service. Hence, this legal principle can be closely associated with several substantive principles such as reasonableness, relevant considerations and so on. This clearly shows why responsiveness is mostly intertwined with other adjacent principles; as we might conceive that about financial fiduciary duty in UK. ${ }^{194}$ According to reasonableness principle, public officials and institutions should strive to provide the highest quality legal services to all beneficiaries within a reasonable timeframe. ${ }^{195}$ It is only possible when these authorities are responsible for demands, expectations and needs of individuals and groups. ${ }^{196}$

\section{Unfettered discretion}

In administrative law, the principle of relevant considerations requires that any public official should consider all aspects of his decision and through analyzing them (principle of accuracy), acts appropriately; principle of unfettered discretion typically supplements these commands by requiring authorities to avoid of any prejudge and to comply with a customary or predetermined conventional process and policy in their decisions. In a more literal sense, administrative decisions should not be taken by a dominant and invariable procedure in relation to all subjects, but should elaborate on any particular issue to provide a suitable decision; as UK judges have emphasized, authority should not decide on all legal situations only in a uniform manner and be bound by a general and definite policy or procedure. ${ }^{197}$ However, this does not deny a systematic function based on

\footnotetext{
194 Roberts v. Hopwood, 1925, AC 578, available at: https://swarb.co.uk/roberts-vhopwood-hl-1925.

195 See Case C-96/82 IAZ v Commission, 1983, ECR 3369, available at: https://eurlex.europa.eu/legal-content/EN/TXT/? uri=CELEX\%3A61982CJ0096.

196 Douglas, Roger, "Administrative Law and Good Governance", in Preston, Noel and Sampford, Charles (eds.), Public Sector Ethics: Finding and Implementing Values, New York, Routledge, 2012, p. 122.

$197 R$ v Home Secretary, 2005, EWCA Civ 744, available at: https://www.refworld. org/cases,GBR_CA_CIV,46c996352.html; Kanthasamy v. Canada (Citizenship and Immigration), $\overline{2} 01 \overline{5}$, SCC 61, available at: https://scc-csc.lexum.com/scc-csc/scc-csc/ 
general policies, ${ }^{198}$ but obliges to analyze each legal status impartially and associate it with proper subordinate norms of those policies. ${ }^{199}$ By similar propositions, the principle is well invoked by german judges. ${ }^{200}$

\section{Proper purpose}

Each public official needs to consider objectives that are consistent with those in content of law in order to make their decision in light of aims of legislator which is reflected in legal rule has assigned the discretion. If authority intends to make a decision by own benefits, this might lead to abuse of power; but improper purpose does not imply that. Actually, in cases where authority intended to act in good faith by considering public interest but decided in contrary to the purpose of law regarding the discretion violates principle of proper purpose; in such cases, due to adoption of a wrong purpose, administrative action is in contrast with provisions of law. Therefore, as it is supposed in UK, ${ }^{201}$ the principle has two meaning sides: obligation of matching intended purpose of competent authority with what is assumed by law (positive proposition); ${ }^{202}$ prohibition of considering a purpose which is not explicitly or implicitly prescribed by law (negative

en/item/15665/index.do; Trinity Western University v. The Law Society of British Columbia, 2015, BCSC 2326, available at: https://scc-csc.lexum.com/scc-csc/scc-csc/en/ item/17140/index.do.

${ }^{198} R$ v. Home Secretary, ex p P and Q, 2001, 2 FLR 383, available at: https:// swarb.co.uk/regina-v-secretary-of-state-for-the-home-department-ex-parte-simms-hl11-feb-1999.

$199 R$ v. Home Secretary, ex p Venables, 1998, AC 407, available at: https://en.wikipedia. org/wiki/R_(Venables_and_Thompson)_v_Home_Secretary; $R$ v. Home Secretary, ex p Hindley, 2001, 1 AC 410, available at: $\bar{h}$ ttps://swarb.co.uk/regina-v-secretary-of-statefor-the-home-department-ex-parte-hindley-hl-30-mar-2000.

200 For instance, see BVerwGE 45, 309.

201 Webb v. Minister of Housing and Local Government, 1965, 2 WLR 755, available at: https://swarb.co.uk/ashbridge-investments-ltd-v-minister-of-housing-and-localgovernment-ca-1965/.

202 Hanks v. Minister of Housing and Local Government, 1963, 1 QB 999, available at: https://swarb.co.uk/hanks-and-others-v-minister-of-housing-and-local-government-1963; Westminster Corporation v London and North Western Railway Co Ltd, 1905, AC 426, available at: https://swarb.co.uk/mayor-and-corporation-of-westminsterv-london-and-north-western-railway-co-hl-24-jul-1905.

Esta obra está bajo una Licencia Creative Commons Atribución-NoComercial-SinDerivar 4.0 Internacional, IIJ-UNAM. 
proposition). ${ }^{203}$ An examples of sub-principles derived from proper purpose would be "legitimate aim" in EU case law; according to which restricting rights and freedoms, are guaranteed by the European convention on human rights, only based on public interest or other legitimate aims is possible. ${ }^{204}$

\section{CONCLUSION}

General principles of administrative law are of the most general, comprehensive, non-positivized and perpetual legal norms which are legitimately recognized in administrative precedent by judges and relatively function in parallel with good administration values in administrative legal system in order to optimize administrative legal order or realize the rule of law in government actions. Their inherent discourses would be conceptualized by some descriptive propositions while the logical and normative correlative links between them as the integrity are strongly retained. Also, by considering optimization and relativity features, obviously we would find out that there is no an absolute distinct principle. Therefore, general principles of administrative law are the same legal principles which are taken by judges in administrative precedent to acquaint them with administrative legal system. Accordingly, if we contrarily argue that GPAL is not exist as a distinct legal norm and it is nothing but the same legal principle, could be justifiable; but this is a right argument if we do not disregard the special features that change a principle in discourse by which it may redefine in the context of an ALS that could be assumed as a sub-norm with administrative nature; this new sub-norm might be called a GPAL. However, by taking antecedent objectivity in the realm of administrative legal system into account, general principles of administrative law can be categorized into classic and modern principles.

The rule of law, legality, ultra vires, error, unauthorized delegation, equality, harm, remedy, equity and Constitutional rights principles are some of the most known classic principle; and mainly, following instances

203 v. Inner London Education Authority, ex parte Westminster City Council, 1986, 1 WLR 28, available at: https://swarb.co.uk/regina-v-inner-london-education-authorityex-parte-westminster-city-council-1986.

204 Piermont v France, 1995, 20 EHRR 301, available at: http://associationline.org/ guidebook/action/read/chapter/4/section/jurisprudence/decision/105. 
can be considered as modern principles that empower good administration values in administrative legal system: legitimate expectations, reasonableness, relevant considerations, proportionality, time limits, transparency, accountability, abuse of power, impartiality, public participation, responsiveness, unfettered discretion and proper purpose; that each one of this principles has been clarified in a general sense. Consequently, the conceptual explanations illustrate that global administrative law requires: protection of substantive dimension of legality as well as procedural one in light of the rule of law by avoiding of errors, exceeding or abusing discretion, unauthorized delegation and harm; also it is necessary to protect constitutional rights and equality while maintaining equity and giving effect to required remedies; mostly, as a modern perspective it is significantly emphasized that public authorities should reasonably, proportionally, impartially, transparently, accountably and responsively act and consider legitimate expectations, relevant considerations and proper purpose in their decisions while they are not fettered or spending excessive time; also there must be an effective opportunity to public participation in order to realization of governmentality and democracy.

Fecha de recepción: 15 de enero de 2019.

Fecha de dictamen: 5 de marzo de 2019. 